\title{
Atmospheric gaseous hydrochloric and hydrobromic acid in urban Beijing, China : detection, source identification and potential atmospheric impacts
}

\section{Fan, Xiaolong}

2021-07-29

Fan , X, Cai , J , Yan , C, Zhao , J , Guo , Y, Li , C, Dällenbach, K, Zheng , F , Lin , Z , Chu , B , Wang , Y, Dada , L , Zha , Q, Du , W , Kontkanen , J , Kurten , T, lyer , S , Kujansuu , J T , Petäjä , T , Worsnop, D R , Kerminen, V-M , Liu , Y, Bianchi , F , Tham , Y J , Yao , L \& Kulmala , M 2021 , ' Atmospheric gaseous hydrochloric and hydrobromic acid in urban Beijing, China : detection, source identification and potential atmospheric impacts ', Atmospheric Chemistry and Physics, vol. 21 , no. 14 , pp. 11437-11452 . https://doi.org/10.5194/acp-21-11437-202

http://hdl.handle.net/10138/333077

https://doi.org/10.5194/acp-21-11437-2021

cc_by

publishedVersion

Downloaded from Helda, University of Helsinki institutional repository.

This is an electronic reprint of the original article.

This reprint may differ from the original in pagination and typographic detail.

Please cite the original version. 


\title{
Atmospheric gaseous hydrochloric and hydrobromic acid in urban Beijing, China: detection, source identification and potential atmospheric impacts
}

\author{
Xiaolong Fan ${ }^{1, \star}$, Jing Cai ${ }^{2} \star$, Chao Yan $^{2}$, Jian Zhao ${ }^{2}$, Yishuo Guo ${ }^{1}$, Chang Li ${ }^{1}$, Kaspar R. Dällenbach ${ }^{2}$, \\ Feixue Zheng ${ }^{1}$, Zhuohui Lin ${ }^{1}$, Biwu Chu ${ }^{3,4}$, Yonghong Wang ${ }^{2}$, Lubna Dada ${ }^{2}$, Qiaozhi Zha ${ }^{2}$, Wei Du ${ }^{2}$, \\ Jenni Kontkanen ${ }^{2}$, Theo Kurtén ${ }^{5}$, Siddhart Iyer ${ }^{6}$, Joni T. Kujansuu ${ }^{1,2}$, Tuukka Petäjä ${ }^{2}$, Douglas R. Worsnop ${ }^{7}$, \\ Veli-Matti Kerminen $^{2}$, Yongchun Liu ${ }^{1}$, Federico Bianchi ${ }^{2}$, Yee Jun Tham ${ }^{8,2}$, Lei Yao ${ }^{2}$, and Markku Kulmala ${ }^{1,2,9}$ \\ ${ }^{1}$ Aerosol and Haze Laboratory, Beijing Advanced Innovation Center for Soft Matter Science and Engineering, \\ Beijing University of Chemical Technology, Beijing 100089, China \\ ${ }^{2}$ Institute for Atmospheric and Earth System Research (Physics), Faculty of Science, University of Helsinki, \\ Helsinki 00560, Finland \\ ${ }^{3}$ State Key Joint Laboratory of Environment Simulation and Pollution Control, Research Center for Eco-Environmental \\ Sciences, Chinese Academy of Sciences, Beijing 100085, China \\ ${ }^{4}$ Center for Excellence in Regional Atmospheric Environment, Institute of Urban Environment, \\ Chinese Academy of Sciences, Xiamen 361021, China \\ ${ }^{5}$ Department of Chemistry, University of Helsinki, Helsinki 00014, Finland \\ ${ }^{6}$ Aerosol Physics Laboratory, Physics Unit, Tampere University, Tampere 33100, Finland \\ ${ }^{7}$ Aerodyne Research Inc., Billerica, Massachusetts 01821, USA \\ ${ }^{8}$ School of Marine Sciences, Sun Yat-Sen University, Zhuhai 519082, China \\ ${ }^{9}$ Joint International Research Laboratory of Atmospheric and Earth System Sciences (JirLATEST), Nanjing University, \\ Nanjing 210023, China \\ « These authors contributed equally to this work.
}

Correspondence: Lei Yao (lei.yao@ helsinki.fi) and Yee Jun Tham (thamyj@ mail.sysu.edu.cn )

Received: 2 December 2020 - Discussion started: 11 December 2020

Revised: 16 June 2021 - Accepted: 1 July 2021 - Published: 29 July 2021

\begin{abstract}
Gaseous hydrochloric $(\mathrm{HCl})$ and hydrobromic acid $(\mathrm{HBr})$ are vital halogen species that play essential roles in tropospheric physicochemical processes. Yet, the majority of the current studies on these halogen species were conducted in marine or coastal areas. Detection and source identification of $\mathrm{HCl}$ and $\mathrm{HBr}$ in inland urban areas remain scarce, thus limiting the full understanding of halogen chemistry and potential atmospheric impacts in the environments with limited influence from the marine sources. Here, both gaseous $\mathrm{HCl}$ and $\mathrm{HBr}$ were concurrently measured in urban Beijing, China, during winter and early spring of 2019. We observed significant $\mathrm{HCl}$ and $\mathrm{HBr}$ concentrations ranging from a minimum value at $1 \times 10^{8}$ molecules $\mathrm{cm}^{-3}(4 \mathrm{ppt})$ and $4 \times 10^{7}$ molecules $\mathrm{cm}^{-3}$
\end{abstract}

(1 ppt) up to $6 \times 10^{9}$ molecules $\mathrm{cm}^{-3}(222 \mathrm{ppt})$ and $1 \times 10^{9}$ molecules $\mathrm{cm}^{-3}(37 \mathrm{ppt})$, respectively. The $\mathrm{HCl}$ and $\mathrm{HBr}$ concentrations are enhanced along with the increase of atmospheric temperature, UVB and levels of gaseous $\mathrm{HNO}_{3}$. Based on the air mass analysis and high correlations of $\mathrm{HCl}$ and $\mathrm{HBr}$ with the burning indicators ( $\mathrm{HCN}$ and $\mathrm{HCNO}$ ), gaseous $\mathrm{HCl}$ and $\mathrm{HBr}$ are found to be related to anthropogenic burning aerosols. The gas-particle partitioning may also play a dominant role in the elevated daytime $\mathrm{HCl}$ and $\mathrm{HBr}$. During the daytime, the reactions of $\mathrm{HCl}$ and $\mathrm{HBr}$ with $\mathrm{OH}$ radicals lead to significant production of atomic $\mathrm{Cl}$ and $\mathrm{Br}$, up to $2 \times 10^{4}$ molecules $\mathrm{cm}^{-3} \mathrm{~s}^{-1}$ and $8 \times 10^{4}$ molecules $\mathrm{cm}^{-3} \mathrm{~s}^{-1}$, respectively. The production rate of atomic $\mathrm{Br}(\mathrm{via} \mathrm{HBr}+\mathrm{OH})$ is $2-3$ times higher 
than that of atomic $\mathrm{Cl}($ via $\mathrm{HCl}+\mathrm{OH})$, highlighting the potential importance of bromine chemistry in the urban area. On polluted days, the production rates of atomic $\mathrm{Cl}$ and $\mathrm{Br}$ are faster than those on clean days. Furthermore, our observations of elevated $\mathrm{HCl}$ and $\mathrm{HBr}$ may suggest an important recycling pathway of halogen species in inland megacities and may provide a plausible explanation for the widespread halogen chemistry, which could affect the atmospheric oxidation in China.

\section{Introduction}

Tropospheric halogen chemistry plays a variety of roles in perturbing the fate of chemical compositions, including ozone $\left(\mathrm{O}_{3}\right)$ and volatile organic compounds (VOCs) in the troposphere (Saiz-Lopez and von Glasow, 2012; Simpson et al., 2015; Artiglia et al., 2017). Halogen radicals, in particular atomic chlorine $(\mathrm{Cl} \bullet)$ and bromine $(\mathrm{Br} \bullet)$, can deplete the $\mathrm{O}_{3}$, react rapidly with VOCs with reaction rates of up to 2 orders of magnitude faster than those of the hydroxyl radical $(\mathrm{OH})$ reaction with VOCs and accelerate the depletion of gaseous elemental mercury (Atkinson et al., 2007; Calvert and Lindberg, 2004). Significant halogen-induced $\mathrm{O}_{3}$ reduction of about $10 \%$ of the annually averaged tropospheric ozone column was reported over the tropical marine boundary layer (Saiz-Lopez et al., 2012). However, in polluted coastal regions with high $\mathrm{NO}_{x}$, the coupling between halogen chemistry and $\mathrm{NO}_{x}$ chemistry contributes to a significant enhancement of ozone production of up to $7 \mathrm{ppb}$ (parts per billion by volume) (Li et al., 2020; Sherwen et al., 2017; Sarwar et al., 2014). Besides affecting the ozone chemistry, the oxidation processes of VOCs by halogen radicals can potentially lead to secondary aerosol production. Wang and Ruiz (2017) demonstrated that the chlorine-initiated oxidation of isoprene contributed to the formation of particulate organochloride and the yield of secondary organic aerosol (SOA) ranged from $7 \%$ to $36 \%$. A recent study also found that the oxidation of $\alpha$-pinene by chlorine atoms yields lowvolatility organic compounds, which are essential precursors for secondary particle formation and growth (Wang et al., 2020).

It is known that sea salt particles are a major source of atomic halogens in the marine environment. Chloride $\left(\mathrm{Cl}^{-}\right)$ and bromide $\left(\mathrm{Br}^{-}\right)$in sea salt particles can be displaced by strong acids (i.e., nitric acid $\left(\mathrm{HNO}_{3}\right)$ and sulfuric acid $\left(\mathrm{H}_{2} \mathrm{SO}_{4}\right)$ ) to release gas-phase hydrogen halides HX (Reaction $\mathrm{R} 1 ; \mathrm{X}=\mathrm{Cl}$ or $\mathrm{Br}$ ) into the atmosphere (Gard et al., 1998; Thornton et al., 2010). The HX then can react with an $\mathrm{OH}$ radical to form a $\mathrm{X} \cdot$ via Reaction $(\mathrm{R} 2)$.
$\mathrm{X}^{-}$(sea salt) $+\mathrm{HNO}_{3} \rightarrow \mathrm{HX}$

$\mathrm{HX}+\mathrm{OH} \rightarrow \mathrm{X} \cdot+\mathrm{H}_{2} \mathrm{O}$

On the other hand, the heterogeneous uptake of dinitrogen pentoxide $\left(\mathrm{N}_{2} \mathrm{O}_{5}\right)$ onto sea salt particles can form nitryl halides $\mathrm{XNO}_{2}$ via Reaction (R3) (Finlayson-Pitts et al., 1989; Osthoff et al., 2008; Tham et al., 2014), which is a reservoir of halogen during the nighttime. At sunrise, the $\mathrm{XNO}_{2}$ undergoes rapid photolysis to liberate highly reactive halogen atom $(\mathrm{X} \cdot$ ), which subsequently reacts with VOCs to produce $\mathrm{HX}$ and peroxy radicals $\left(\mathrm{RO}_{2}\right.$; Reactions $\mathrm{R} 4$ and $\left.\mathrm{R} 5\right)$. In addition, the heterogeneous oxidation of $\mathrm{Br}^{-}$by $\mathrm{O}_{3}$ at the aqueous phase-vapor interface can lead to the formation of a precomplex intermediate $\left(\mathrm{Br} \cdot \mathrm{OOO}^{-}\right)$, which contributes to the formation of atmospheric $\mathrm{HOBr}$ (Artiglia et al., 2017).

$$
\begin{aligned}
& \mathrm{X}^{-} \text {(sea salt) }+\mathrm{N}_{2} \mathrm{O}_{5} \rightarrow \mathrm{XNO}_{2}+\mathrm{NO}_{3}^{-} \\
& \mathrm{XNO}_{2}+h v \rightarrow \mathrm{X} \cdot+\mathrm{NO}_{2} \\
& \mathrm{X} \cdot+\mathrm{RH} \rightarrow \mathrm{HX}+\mathrm{RO}_{2}
\end{aligned}
$$

The atmospheric lifetimes of hydrochloric $(\mathrm{HCl})$ and hydrobromic acid $(\mathrm{HBr})$ due to Reaction (R2) are approximately 35.6 and $2.5 \mathrm{~h}$ (when $\mathrm{OH}=1 \times 10^{7}$ molecules $\mathrm{cm}^{-3}$ ), respectively, making them a significant daytime recycling source of atomic halogen in the marine atmosphere. Riedel et al. (2012) showed that the reaction of $\mathrm{HCl}$ with $\mathrm{OH}$ accounts for about $45 \%$ of the integrated $\mathrm{Cl}$ atom production over the entire day along the Santa Monica Bay of Los Angeles (Riedel et al., 2012). Another shipborne study reported that the $\mathrm{Cl}$ atom production rate peaks at $3 \times 10^{5}$ molecules $\mathrm{cm}^{-3} \mathrm{~s}^{-1}$ during the noontime in southern coastal California (Crisp et al., 2014). The produced $\mathrm{HCl}$ and $\mathrm{HBr}$ can also end up in particle phase during the nighttime (Chen et al., 2016; Roberts et al., 2019; Crisp et al., 2014), further promoting the heterogeneous reaction of $\mathrm{N}_{2} \mathrm{O}_{5}$ (Reaction R3).

The discovery of Thornton et al. (2010) has changed the paradigm of halogen chemistry, where it was thought to be restricted to the marine environment (Thornton et al., 2010). A significant source of atomic chlorine from the heterogeneous reaction of $\mathrm{N}_{2} \mathrm{O}_{5}$ onto chloride aerosol (Reaction R3) was observed in Boulder, United States, which is $1400 \mathrm{~km}$ from the nearest coastline, indicating that active chlorine chemistry also occurs in regions far from the ocean (Thornton et al., 2010). Follow-up studies have confirmed the presence of halogen activation spreading over the continental regions of North America, Canada, Europe and Asia (Mielke et al., 2011; Phillips et al., 2012; Riedel et al., 2013; Tham et al., 2016; Wang et al., 2017; Tham et al., 2018; Liu et al., 2017; Xia et al., 2020; Zhou et al., 2018; McNamara et al., 2020). These findings suggest the crucial role of $\mathrm{HCl}$ gas-particle partitioning in sustaining the aerosol chloride concentrations in continental regions for Reaction (R3) to take place (Brown and Stutz, 2012). 
On the global scale, sea salt sprays were estimated to be the dominant source of halogens such as $\mathrm{Cl}$ and $\mathrm{Br}$ (X. Wang et al., 2019; Keene et al., 1999). Through acid displacement and other heterogeneous processes, 64 and $6.2 \mathrm{Tg} \mathrm{a}^{-1}$ gasphase inorganic $\mathrm{Cl}$ and $\mathrm{Br}$ from sea salt were emitted to the troposphere, while anthropogenic emissions such as biomass burning, fossil combustion and incineration were supposed to be minor on a global scale (X. Wang et al., 2019; Keene et al., 1999). For the emissions of $\mathrm{Cl}$, anthropogenic emissions were quite crucial for both gaseous and particulate $\mathrm{Cl}$ in the urban environment and heavily polluted areas. For example, the anthropogenic emissions for gaseous $\mathrm{HCl}$ and particulate $\mathrm{Cl}$ were 458 and $486 \mathrm{Gg}$ in 2014 in China, of which biomass burning is the largest contributor (Fu et al., 2018). Many recent field studies reported elevated $\mathrm{ClNO}_{2}$ and particulate chloride concentrations in the plumes influenced by biomass burning and coal-fired power plants, suggesting they could be the driving force for the $\mathrm{Cl}$ activation process in continental areas (Riedel et al., 2013; Tham et al., 2016; Wang et al., 2017; Liu et al., 2017; Yang et al., 2018). Furthermore, Bannan et al. (2019) showed that $\mathrm{ClNO}_{2}$ is consistently formed at a landfill site in London, highlighting the potential contribution from landfill emissions of $\mathrm{Cl}$ in promoting Reactions (R3) and (R4) (Bannan et al., 2019). Other possible anthropogenic $\mathrm{Cl}$ sources include the emissions from industry and water and sewage treatment plants (Hara et al., 1989; Graedel and Keene, 1995; Thornton et al., 2010). During the wintertime, the use of road salt could also be a dominant source of atmospheric $\mathrm{Cl}$ in city areas (McNamara et al., 2020).

Atmospheric bromine is much less abundant than chlorine in the stratosphere, with concentrations of around $25 \mathrm{ppt}$ (parts per trillion by volume) compared to $3.7 \mathrm{ppb}$ of chlorine (Bedjanian and Poulet, 2003; Rotermund et al., 2021). $\mathrm{HBr}$ is known as a principal bromine sink species for ozone loss chemistry in the stratosphere, showing an average concentration of $1.3 \pm 0.39 \mathrm{ppt}$ between 20.0 and $36.5 \mathrm{~km}$ altitude (Bedjanian and Poulet, 2003; Nolt et al., 1997; Yang et al., 2005), and also one of the dominant inorganic bromine species in the marine boundary layer, free troposphere and tropical tropopause layer as well (Fernandez et al., 2014; Glasow and Crutzen, 2014; Nolt et al., 1997; Bedjanian and Poulet, 2003). In the urban environment, atmospheric Br was previously known to be strongly affected by traffic emissions since ethylene dibromide $\left(\mathrm{C}_{2} \mathrm{H}_{4} \mathrm{Br}_{2}\right)$ used to be used as an anti-knock compound in leaded gasoline (Glasow and Crutzen, 2014). Yet, since the phasing out of leaded gasoline, long-term atmospheric $\mathrm{Br}$ has exhibited a continuous decreasing trend for 2 to 3 decades in Germany (Lammel et al., 2002), and a similar situation is expected in Beijing as the usage of leaded gasoline was banned from the years around the 2000s in China (Cai et al., 2017).

Despite the advances in the understanding of concentrations and sources of global halogen species, atmospheric gaseous $\mathrm{HCl}$ and $\mathrm{HBr}$ in the continental and especially urban environments are much less studied. Some limited studies focused on atmospheric $\mathrm{HCl}$; for example, Crisp et al. (2014) summarized that the concentration of $\mathrm{HCl}$ is typically less than $1 \mathrm{ppb}$ over the continental regions, and McNamara et al. (2020) measured the concentration of $\mathrm{HCl}$ to be around $100 \mathrm{ppt}$ from inland sources, while an airborne measurement showed $\mathrm{HCl}$ concentrations of around $100 \mathrm{ppt}$ to be typically observed over the land area of the northeast United States, except near power plant plumes with concentrations over 1 ppb (Crisp et al., 2014; McNamara et al., 2020; Haskins et al., 2018). Furthermore, much less information is available on the presence of $\mathrm{HBr}$ in the continental environment. Until very recently, an airborne measurement detected significant levels of gas-phase reactive bromine species in the exhaust of coal-fired power plants (Lee et al., 2018). Therefore, the measurement of gas-phase $\mathrm{HCl}$ and $\mathrm{HBr}$ in inland urban environments is necessary to fully assess their effects on the tropospheric chemistry, such as gas-particle partitioning effects on the particulate halide concentrations that can undergo rapid activation via Reaction (R3). These would be more important in polluted regions such as the North China Plain, where Beijing is located and a large amount of chloride is emitted to the atmosphere (Tham et al., 2016; Zhou et al., 2018; Fu et al., 2018).

In this study, we deployed a chemical ionizationatmospheric pressure interface-long-time-of-flight mass spectrometer (CI-APi-LTOF) to measure the atmospheric gas-phase $\mathrm{HCl}$ and $\mathrm{HBr}$ from 1 February to 31 March 2019, in urban Beijing, China. To the best of our knowledge, it is the first time a simultaneous measurement of $\mathrm{HCl}$ and $\mathrm{HBr}$ is presented with high time resolution in urban Beijing. In addition, we identify the potential source that contributed to the high levels of gaseous $\mathrm{HCl}$ and $\mathrm{HBr}$ during wintertime and early springtime. In addition, we estimate the contribution of gaseous $\mathrm{HCl}$ and $\mathrm{HBr}$ to the production rates of atomic $\mathrm{Cl}$ and $\mathrm{Br}$ in urban Beijing.

\section{Methodology}

\subsection{Sampling site}

The field measurements were conducted at Beijing University of Chemical Technology (BUCT) monitoring station $\left(39.94^{\circ} \mathrm{N}, 116.30^{\circ} \mathrm{E}\right)$, located in an urban area of Beijing, China (Fig. 1); the nearest coastline is located about $150 \mathrm{~km}$ away in the southeast. The sampling site is about $130 \mathrm{~m}$ north of the Zizhuyuan Road and $550 \mathrm{~m}$ west of the West Third Ring Road, which is one of the main roads in Beijing. Besides the effect of traffic, this site is also surrounded by local commercial properties and residential dwellings. Thus, the BUCT sampling site can be regarded as a typical urban site. More information about this sampling site can be found in previous studies (Cai et al., 2020; Kontkanen et al., 2020; Zhou et al., 2020; Chu et al., 2021). The instruments were 
deployed on the roof of a teaching building, which is approximately $15 \mathrm{~m}$ above ground level.

\subsection{CI-APi-LTOF mass spectrometer}

The working principle of CI-APi-LTOF (Aerodyne Research Inc. and Tofwerk AG) has been described elsewhere (Yao et al., 2020; Eisele and Tanner, 1993; Yao et al., 2018); therefore only details relevant to this present work are discussed here. A typical mass spectrum during our field measurement is depicted in Fig. S1. The dominant reagent ions were nitrate ions $\left(\mathrm{NO}_{3}^{-}\right.$, and $\left.\mathrm{HNO}_{3} \cdot \mathrm{NO}_{3}^{-}\right)$and nitrite ions $\left(\mathrm{NO}_{2}^{-}\right)$. Among them, nitrate ions were generated by exposure of sheath flow (pure air with $\mathrm{RH} \sim 5 \%$ ), which carried gaseous $\mathrm{HNO}_{3}$. Besides the nitrate ions that acted as dominate reagent ions, nitrite ions were formed from the reaction of a small amount of $\mathrm{NO}_{2}(\sim 1 \mathrm{ppb})$ in the sheath flow with $\mathrm{O}_{2}^{-}$and $\mathrm{OH}^{-}$, which were generated from the exposure of sheath flow (pure air with $\mathrm{RH} \sim 5 \%$ ) to an X-ray source (Hamamatsu L9491) (Fig. S5) (Arnold et al., 1995; Skalny et al., 2004). Considering nitrate ions were still the dominant reagent ions (Fig. S1), the CI-APi-LTOF was actually operated as a typical nitrateCI-APi-LTOF.

Ambient air was drawn into the $\mathrm{CI}$ inlet through a $0.75 \mathrm{in}$. stainless steel tube with a flow of $\sim 8 \mathrm{~L} \mathrm{~min}^{-1}$. A small mixed flow $\left(\sim 0.8 \mathrm{~L} \mathrm{~min}^{-1}\right.$ controlled by a critical orifice with $300 \mu \mathrm{m}$ diameter) entered the APi-LTOF and was analyzed. The CI-APi-LTOF was operated in the negative Vmode with a mass resolving power of $\sim 10000 \mathrm{Th} / \mathrm{Th}$ and a mass accuracy better than $5 \mathrm{ppm}$. Data of CI-APi-LTOF were acquired with $5 \mathrm{~s}$ time resolution, and the recorded data were further analyzed with the MATLAB tofTools package (Junninen et al., 2010).

\subsection{Detection and quantification of $\mathrm{HCl}$ and $\mathrm{HBr}$}

From Table 1, it can be seen that the gas-phase acidity $(-\Delta G)$ of $\mathrm{HCl}$ is $1354 \mathrm{~kJ} \mathrm{~mol}^{-1}$, which is larger than that of $\mathrm{HNO}_{3}\left(1329 \mathrm{~kJ} \mathrm{~mol}^{-1}\right)$. In addition, the enthalpy $(\Delta \mathrm{H})$ of $\mathrm{HNO}_{3}$ and $\mathrm{Cl}^{-}$is $32.8 \mathrm{kcal} \mathrm{mol}^{-1}$, which is higher than that of $\mathrm{HCl}$ and $\mathrm{NO}_{3}^{-}\left(22.9 \mathrm{kcal} \mathrm{mol}^{-1}\right)$, hinting that the reaction of $\mathrm{HCl}$ and $\mathrm{NO}_{3}^{-}$was unlikely to occur (Fig. S4a). Additionally, a previous study showed that the reaction rate $\left(<10^{-12}\right.$ molecules $\left.\mathrm{cm}^{-3} \mathrm{~s}^{-1}\right)$ between $\mathrm{NO}_{3}^{-}$and $\mathrm{HCl}$ was significantly less than that $\left(1.4 \times 10^{-9}\right.$ molecules $\left.\mathrm{cm}^{-3} \mathrm{~s}^{-1}\right)$ of $\mathrm{NO}_{2}^{-}$with $\mathrm{HCl}$ (Ferguson et al., 1972). Therefore, the $\mathrm{HCl}$ is likely mainly charged by $\mathrm{NO}_{2}^{-}$instead of $\mathrm{NO}_{3}^{-}$to result in $\mathrm{Cl}^{-}$formation. The ion-molecule reaction between nitrite ions and $\mathrm{HCl}$ can be written as follows (Ferguson et al., 1972):

$\mathrm{NO}_{2}^{-}+\mathrm{HCl} \rightarrow \mathrm{Cl}^{-}+\mathrm{HNO}_{2}$.

In addition to $\mathrm{NO}_{2}^{-}, \mathrm{HCl}$ can also react with $\mathrm{O}_{2}^{-}$, leading to $\mathrm{Cl}^{-}$formation via Reaction (R7).

$\mathrm{O}_{2}^{-}+\mathrm{HCl} \rightarrow \mathrm{Cl}^{-}+\mathrm{HO}_{2}$
Therefore, $\mathrm{HCl}$ can be quantified according to

$[\mathrm{HCl}]=C_{\mathrm{HCl}} \times \frac{\left(\mathrm{Cl}^{-}\right)}{\left(\mathrm{NO}_{2}^{-}\right)+\left(\mathrm{O}_{2}^{-}\right)}$,

where $C_{\mathrm{HCl}}$ (in units of molecules $\mathrm{cm}^{-3}$ ) is a calibration coefficient of $\mathrm{HCl} .\left(\mathrm{Cl}^{-}\right),\left(\mathrm{NO}_{2}^{-}\right)$and $\left(\mathrm{O}_{2}^{-}\right)$represent the signals of $\mathrm{Cl}^{-}, \mathrm{NO}_{2}^{-}$and $\mathrm{O}_{2}^{-}$from CI-APi-LTOF, respectively. Based on ambient data, a very small fraction (less than $5 \%$ ) of $\mathrm{Cl}^{-}$(or $\mathrm{HCl}$ ) would react with $\mathrm{HNO}_{3}$ (or $\mathrm{NO}_{3}^{-}$) in the sheath flow to form $\mathrm{Cl}^{-} \cdot \mathrm{HNO}_{3}$ (or $\mathrm{HCl} \cdot \mathrm{NO}_{3}^{-}$). Thus, the signals of $\mathrm{Cl}^{-} \cdot \mathrm{HNO}_{3}$ (or $\mathrm{HCl} \cdot \mathrm{NO}_{3}^{-}$) were not taken into account for $\mathrm{HCl}$ quantification. The background measurement was carried out by sampling zero air. Figure S7 shows that the background signals were significantly lower than those of ambient air and injected $\mathrm{HCl}$ and $\mathrm{HBr}$. The limits of detection (LODs, $3 \sigma$ ) were $1 \times 10^{8}$ and $1 \times 10^{7}$ molecules $\mathrm{cm}^{-3}$ (i.e., 4 and $0.5 \mathrm{ppt}$ ) for $\mathrm{HCl}$ and $\mathrm{HBr}$, respectively. Using $4 \mathrm{~d}$ synchronous gaseous $\mathrm{HCl}$ concentrations measured by the Monitor for AeRosols and Gases in Ambient air (MARGA; Metrohm Inc., Switzerland), an indirect calibration was adopted to quantify the $\mathrm{HCl}$ measured by the CI-APi-LTOF (Sect. S5 in the Supplement). The obtained calibration factor $C_{\mathrm{HCl}}$ for $\mathrm{HCl}$ is $3 \pm 0.1 \times 10^{12}$ molecules $\mathrm{cm}^{-3}$ (Fig. S8b), and an uncertainty of $\pm 30 \%$ (Sect. S5) was applied to the reported $\mathrm{HCl}$ concentrations. Similar to $\mathrm{HCl}$, the same uncertainty was also adopted for $\mathrm{HBr}$ mixing ratios. It should be noted that our assumptions lead towards a semi-quantitative estimation of $\mathrm{HBr}$ concentrations, due to other potential uncertainties (e.g., different sensitivities of $\mathrm{HCl}$ and $\mathrm{HBr}$ ) not being taken into account.

On the basis of $-\Delta G$ of $\mathrm{HBr}, \mathrm{HNO}_{3}, \mathrm{HNO}_{2}$ and $\mathrm{HO}_{2}$ and the enthalpy $(\Delta \mathrm{H})$ calculations (Table 1, Figs. 2 and $\mathrm{S} 4$ ), besides the reaction with $\mathrm{NO}_{2}^{-}$and $\mathrm{O}_{2}^{-}$, similar to $\mathrm{HCl}$, some $\mathrm{HBr}$ could also react with $\mathrm{NO}_{3}^{-}$to form $\mathrm{Br}^{-}$via Reaction (R8) (Ferguson et al., 1972).

$\mathrm{NO}_{3}^{-}+\mathrm{HBr} \rightarrow \mathrm{Br}^{-}+\mathrm{HNO}_{3}$

Hence, $\mathrm{HBr}$ should be quantified according to

$[\mathrm{HBr}]=C_{\mathrm{HBr}} \times \frac{\left(\mathrm{Br}^{-}\right)}{\left(\mathrm{NO}_{2}^{-}\right)+\left(\mathrm{O}_{2}^{-}\right)+\left(\mathrm{NO}_{3}^{-}\right)}$,

where $C_{\mathrm{HBr}}$ (in units of molecules $\mathrm{cm}^{-3}$ ) is a calibration coefficient of $\mathrm{HBr}$. $\left(\mathrm{Br}^{-}\right),\left(\mathrm{NO}_{2}^{-}\right),\left(\mathrm{O}_{2}^{-}\right)$and $\left(\mathrm{NO}_{3}^{-}\right)$represent the signals of $\mathrm{Br}^{-}, \mathrm{NO}_{2}^{-}, \mathrm{O}_{2}^{-}$and $\mathrm{NO}_{3}^{-}$from CI-APi-LTOF, respectively. However, as direct calibration for $\mathrm{HBr}$ was not available, the calibration coefficient of $\mathrm{HCl}\left(C_{\mathrm{HCl}}\right)$ was utilized to semi-quantify $\mathrm{HBr}$ based on the following equation:

$[\mathrm{HBr}]=C_{\mathrm{HCl}} \times \frac{\left(\mathrm{Br}^{-}\right)}{\left(\mathrm{NO}_{2}^{-}\right)+\left(\mathrm{O}_{2}^{-}\right)}$.

Since the enthalpies $(\Delta \mathrm{H})$ of $\mathrm{HBr} \cdot \mathrm{NO}_{3}^{-}$formed by $\mathrm{HBr}$ with $\mathrm{NO}_{3}^{-}\left(27.3 \mathrm{kcal} \mathrm{mol}^{-1}\right)$ and $\mathrm{Br}^{-}$with $\mathrm{HNO}_{3}$ 


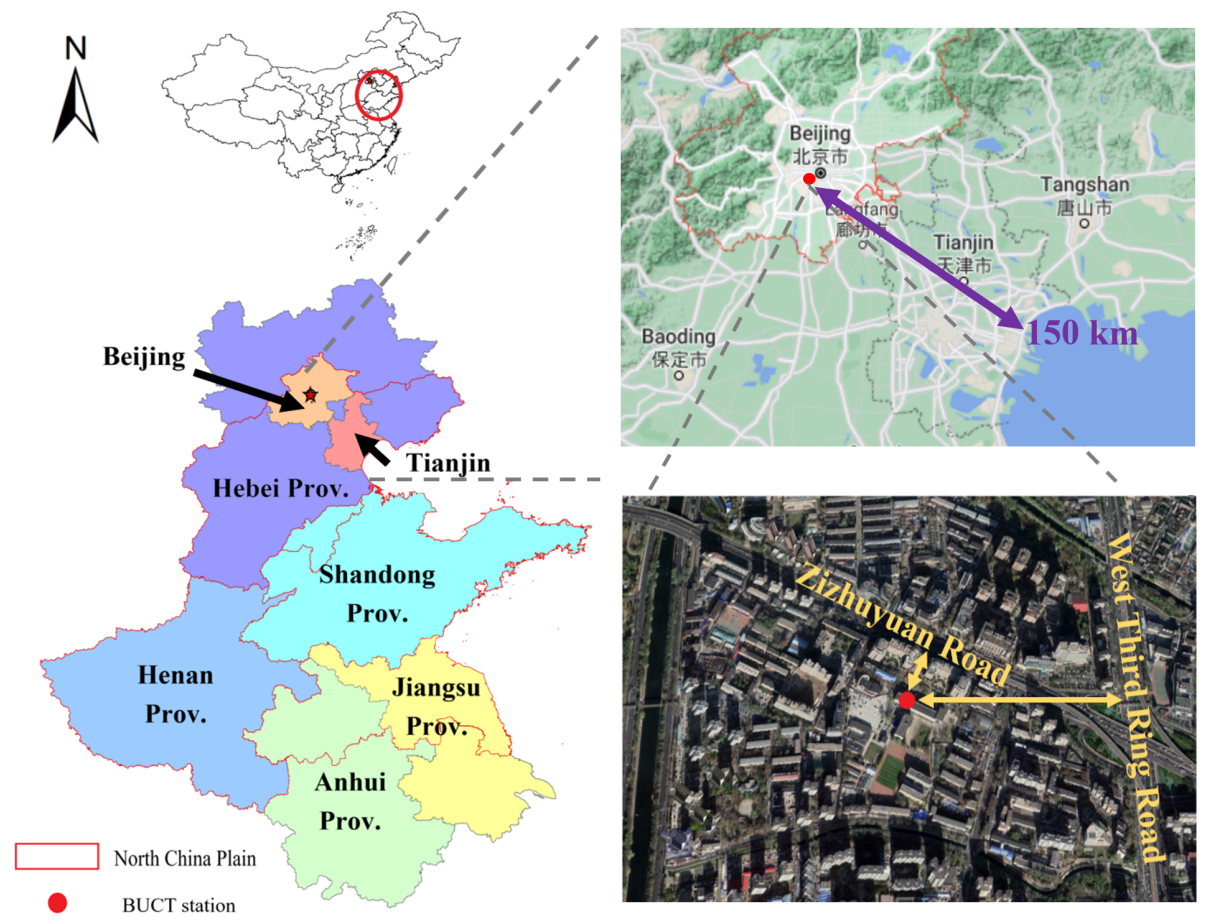

Figure 1. The location of BUCT measurement station. The terrain and satellite maps were revised from (C Google Maps.

Table 1. Gas-phase acidities and deprotonated anion of a few compounds of interest.

\begin{tabular}{llrl}
\hline Compounds & Formula & $-\Delta G^{*}\left(\mathrm{~kJ} \mathrm{~mol}^{-1}\right)$ & Deprotonated anion \\
\hline Hydrobromic acid & $\mathrm{HBr}$ & 1319 & $\mathrm{Br}^{-}$ \\
Nitric acid & $\mathrm{HNO}_{3}$ & 1329 & $\mathrm{NO}_{3}^{-}$ \\
Hydrochloric acid & $\mathrm{HCl}$ & 1354 & $\mathrm{Cl}^{-}$ \\
Nitrous acid & $\mathrm{HONO}$ & 1396 & $\mathrm{NO}_{2}^{-}$ \\
Isocyanic acid & $\mathrm{HCNO}$ & 1415 & $\mathrm{CNO}^{-}$ \\
Hydrocyanic acid & $\mathrm{HCN}$ & 1433 & $\mathrm{CN}^{-}$ \\
Hydroperoxy radical & $\mathrm{HO}$ & 1450 & $\mathrm{O}_{2}^{-}$ \\
Hypobromous acid & $\mathrm{HOBr}$ & 1460 & $\mathrm{BrO}^{-}$ \\
Hypochlorous acid & $\mathrm{HOCl}$ & 1461 & $\mathrm{ClO}^{-}$ \\
\hline
\end{tabular}

${ }^{*}$ Gas-phase acidity is defined as $-\Delta G$ for the protonation reaction $\left(\mathrm{H}^{+}+\mathrm{A}^{-} \rightarrow \mathrm{HA}\right)$. Data are obtained from the NIST Chemistry WebBook.

$\left(27.9 \mathrm{kcal} \mathrm{mol}^{-1}\right)$ were very close to each other (Fig. S4b), it was difficult to quantify the specific contribution to $\mathrm{Br}^{-}$ from the reaction of $\mathrm{HBr}$ with $\mathrm{NO}_{3}^{-}$. Also, the ratios of $\mathrm{Br}^{-} \cdot \mathrm{HNO}_{3}$ (or $\mathrm{HBr} \cdot \mathrm{NO}_{3}^{-}$) to $\mathrm{Br}^{-}$were less than $4 \%$. Therefore, in Eq. (3), the reaction pathway of $\mathrm{HBr}$ with $\mathrm{NO}_{3}^{-}$was not considered. The presented $\mathrm{HBr}$ concentrations should be treated as semi-quantitative ones.

To confirm these ion-molecule reactions, high concentrations (undetermined) of gaseous $\mathrm{HCl}$ and $\mathrm{HBr}$ were mixed with zero air generated from a zero-air generator (Aadco 737) and then measured by CI-APi-LTOF (Sect. S4). After the injection of $\mathrm{HCl}$ and $\mathrm{HBr}$, the signals of $\mathrm{Cl}^{-}, \mathrm{Br}^{-}$, $\mathrm{Cl}^{-} \cdot \mathrm{HNO}_{3}$ (or $\mathrm{HCl} \cdot \mathrm{NO}_{3}^{-}$) and $\mathrm{Br}^{-} \cdot \mathrm{HNO}_{3}\left(\right.$ or $\mathrm{HBr} \cdot \mathrm{NO}_{3}^{-}$) started to increase (Fig. S7), confirming that $\mathrm{HCl}$ and $\mathrm{HBr}$ can be detected as $\mathrm{Cl}^{-}, \mathrm{Br}^{-}, \mathrm{Cl}^{-} \cdot \mathrm{HNO}_{3}$ and $\mathrm{Br}^{-} \cdot \mathrm{HNO}_{3}$ by CI-APi-LTOF.

\subsection{Other auxiliary measurements}

Gaseous $\mathrm{HCN}$ and $\mathrm{HCNO}$ can also be detected by $\mathrm{O}_{2}^{-}$ through the ion-molecule reactions as follows:

$\mathrm{O}_{2}^{-}+\mathrm{HCN} \rightarrow \mathrm{CN}^{-}+\mathrm{HO}_{2}$

$\mathrm{O}_{2}^{-}+\mathrm{HCNO} \rightarrow \mathrm{CNO}^{-}+\mathrm{HO}_{2}$.

The $-\Delta G$ values of $\mathrm{HCN}$ and $\mathrm{HCNO}$ are 1433 and $1415 \mathrm{~kJ} \mathrm{~mol}^{-1}$, respectively, which are higher than the value of $\mathrm{NO}_{2}^{-}\left(1393 \mathrm{~kJ} \mathrm{~mol}^{-1}\right)$ (Table 1) and lower than that of $\mathrm{O}_{2}^{-}$ $\left(1450 \mathrm{~kJ} \mathrm{~mol}^{-1}\right)$. Therefore, HCN and HCNO are able to be 


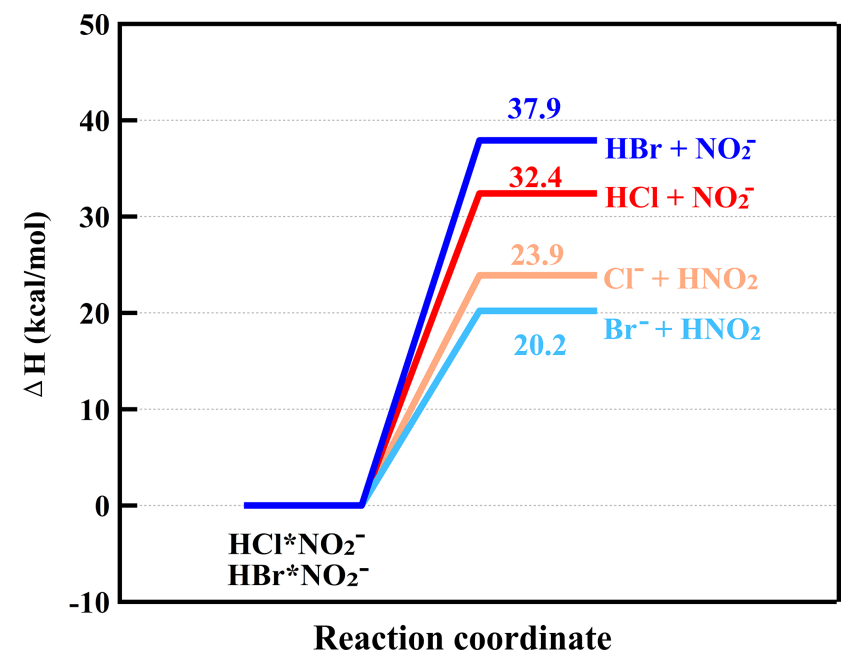

Figure 2. The calculated enthalpies of $\mathrm{HCl} \cdot \mathrm{NO}_{2}^{-}$formed by $\mathrm{HCl}$ with $\mathrm{NO}_{2}^{-}$and $\mathrm{Cl}^{-}$with $\mathrm{HNO}_{2}$ and enthalpies of $\mathrm{HBr} \cdot \mathrm{NO}_{2}^{-}$ formed by $\mathrm{HBr}$ with $\mathrm{NO}_{2}^{-}$and $\mathrm{Br}^{-}$with $\mathrm{HNO}_{2}$ at the DLPNOCCSD(T)/def2-QZVPP// $\omega$ B97X-D/aug-cc-pVTZ-PP level of theory.

charged by $\mathrm{O}_{2}^{-}$(but not $\mathrm{NO}_{2}^{-}$) via a deprotonation reaction to lead to $\mathrm{CN}^{-}$and $\mathrm{CNO}^{-}$formation. In this study, direct calibrations for $\mathrm{HCN}$ and $\mathrm{HCNO}$ were not available. Instead, the normalized signals of $\mathrm{CN}^{-}$and $\mathrm{CNO}^{-}$by $\mathrm{O}_{2}^{-}$were tentatively utilized to indicate the abundance and trend of $\mathrm{HCN}$ and $\mathrm{HCNO}$.

The meteorological parameters, including temperature and UVB intensities, were recorded by a weather station (Vaisala Inc., Finland). $\mathrm{NO}_{2}$ was measured with a Thermo $42 \mathrm{i} \mathrm{NO}-$ $\mathrm{NO}_{2}-\mathrm{NO}_{x}$ analyzer (Thermal Environment Instruments Inc. USA). The mass concentrations of particulate chlorine and black carbon (BC) in $\mathrm{PM}_{2.5}$ were measured by a timeof-flight aerosol chemical speciation monitor (ToF-ACSM, Aerodyne Research Inc., USA) and an aethalometer (AE33, Magee Inc., USA), respectively (Sect. S1 in the Supplement).

Meanwhile, we applied $24 \mathrm{~h}$ air mass back trajectory and potential source contribution function (PSCF) analyses to help elucidate the potential source regions (i.e., air masses) of high levels of $\mathrm{HCl}$ and $\mathrm{HBr}$. The detailed descriptions of PSCF and air mass trajectory analysis are described in the Supplement (Sect. S6) and previous literature (Wang, 2014; Y. Q. Wang, 2019). It is noted that the lifetime of gaseous $\mathrm{HCl}$ and $\mathrm{HBr}$ could be shorter than the length of the air mass trajectories. These analyses mainly aimed to point out the source regions of pollutant air masses that brought high levels of $\mathrm{Cl}$ and $\mathrm{Br}$ rather than the real-time origins of air parcels.

\section{Results and discussions}

\section{1 $\mathrm{HCl}$ and $\mathrm{HBr}$ measurement}

Figure 3 shows the time series of gaseous $\mathrm{HCl}$ and $\mathrm{HBr}$, temperature $(T)$ and ultraviolet radiation $b$ (UVB, 280$315 \mathrm{~nm}$ ) intensities for the entire measurement period in winter and early spring of 2019 (February to April). High concentrations of $\mathrm{HCl}$ and $\mathrm{HBr}$ were observed for the whole measurement period, with a clear diurnal variation (Fig. 3g). The mean concentrations of $\mathrm{HCl}$ and $\mathrm{HBr}$ are $1 \times 10^{9}$ molecules $\mathrm{cm}^{-3}(37 \mathrm{ppt})$ and $2 \times 10^{8}$ molecules $\mathrm{cm}^{-3}$ (7 ppt), respectively. The maximum concentrations reach up to $6 \times 10^{9}$ molecules $\mathrm{cm}^{-3}(222 \mathrm{ppt})$ for $\mathrm{HCl}$ and $1 \times 10^{9}$ molecules $\mathrm{cm}^{-3}$ (37 ppt) for $\mathrm{HBr}$ during the daytime. The concentrations of $\mathrm{HCl}$ and $\mathrm{HBr}$ showed a similar change in atmospheric temperature and UVB. For the first period of measurement (from 1 to 15 February), $\mathrm{HCl}$ and $\mathrm{HBr}$ concentrations are lower when the atmospheric temperature is close to $0^{\circ}$ and the UVB intensities are relatively low. Yet, for the later period of March, the $\mathrm{HCl}$ and $\mathrm{HBr}$ concentrations begin to increase, along with the rising of temperature and UVB. In late March, even with higher temperature, due to the lower abundance of $\mathrm{HNO}_{3}$ and particulate chloride, the $\mathrm{HCl}$ and $\mathrm{HBr}$ concentrations remain at a relatively low level (Fig. 3).

The diurnal cycles of $\mathrm{HCl}$ and $\mathrm{HBr}$ are depicted in Fig. 4a and $\mathrm{b}$, respectively. The $\mathrm{HCl}$ concentrations are typically higher than $\mathrm{HBr}$ by approximately an order of magnitude; nevertheless, the diel patterns showed by these two species are quite similar to each other. It is noticed that both $\mathrm{HCl}$ and $\mathrm{HBr}$ began to increase after sunrise, and a relatively high concentration was observed during the daytime (08:00 to 17:00). From Fig. 4d, it also can be found that elevated $\mathrm{HCl}$ is associated with high temperature and $\left[\mathrm{NO}_{2}\right] \times[\mathrm{OH}]$ value during the daytime. The reaction of $\mathrm{NO}_{2}$ with the $\mathrm{OH}$ radical being one of the dominant formation pathways of gaseous $\mathrm{HNO}_{3}$ during the daytime (Stavrakou et al., 2013) implies that strong photochemical reactions and the following potential elevated $\mathrm{HNO}_{3}$ could intensify the $\mathrm{HCl}$ release from particulate chloride in the daytime from 08:00 to 17:00. The $\mathrm{OH}$ radical concentrations were calculated using $J_{\mathrm{O} 1 \mathrm{D}}$ (Sect. S8). This phenomenon is consistent with our observation results above where the increase of temperature and UVB could reinforce the formation of chemicals (e.g., $\mathrm{HNO}_{3}$ ) that promote the gas-particle partitioning or directly increase the gas-phase formation rate of $\mathrm{HCl}$ and $\mathrm{HBr}$ (Crisp et al., 2014; Riedel et al., 2012), thus further enhancing the $\mathrm{HCl}$ and $\mathrm{HBr}$ (Fig. 3). Although there is no direct measurement of particulate bromide $(\mathrm{Br})$, considering the similarity in diurnal patterns and good correlation $(r=0.70)$ between $\mathrm{HBr}$ and $\mathrm{HCl}$ (Fig. 4c) and $\mathrm{HBr}$ tracking well with the temperature and $\left[\mathrm{NO}_{2}\right] \times[\mathrm{OH}]$ (see Fig. 3), it is rational to suppose $\mathrm{HBr}$ also predominantly derived from the gas-particle partitioning process. The contribution by the reaction of bromine atoms with hydrocarbons to form $\mathrm{HBr}$ is likely not the dom- 


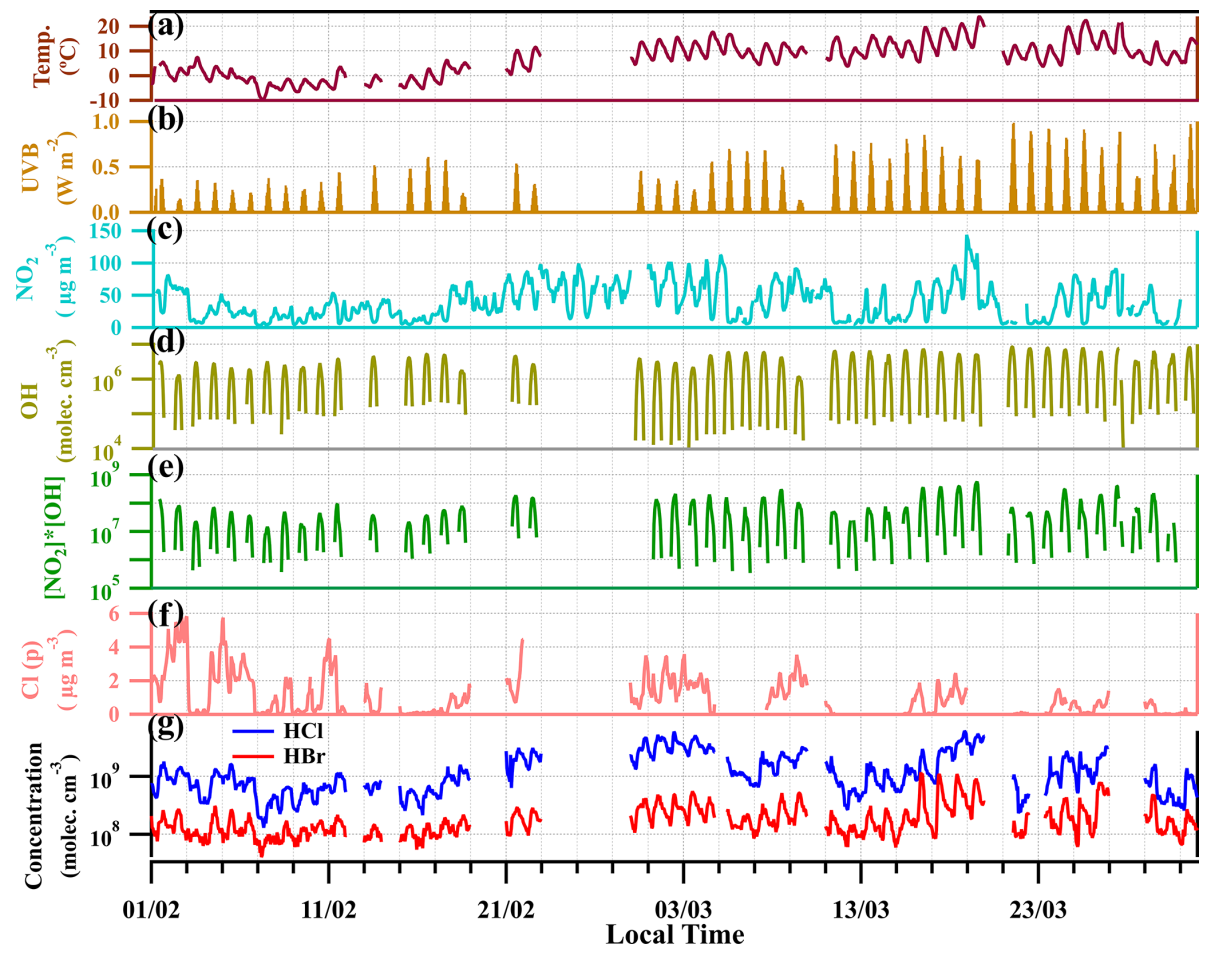

Figure 3. Time profiles of temperature (a), UVB intensities $(\mathbf{b}), \mathrm{NO}_{2}$ concentration $(\mathbf{c}), \mathrm{OH}$ concentration from calculation $(\mathbf{d}),\left[\mathrm{NO} \mathrm{H}_{2}\right] \times[\mathrm{OH}]$ $\left(\mu \mathrm{g} \mathrm{m}^{-3} \times\right.$ molecules $\left.\mathrm{cm}^{-3}\right)(\mathbf{e})$, particulate chloride concentration $(\mathrm{Cl}(p))(\mathbf{f})$ and the mixing ratios of $\mathrm{HCl}$ and $\mathrm{HBr}(\mathrm{g})$. The data points are in hourly average intervals.

inant pathway as the bromine atom is less reactive to hydrocarbons compared to the chlorine atom and most often reacts with ozone (Simpson et al., 2015).

Our observation of daily averaged mass concentrations of particulate chloride $(\mathrm{Cl}(p))$ in $\mathrm{PM}_{2.5}$ showed a similar trend with daily averaged mixing ratios of gaseous $\mathrm{HCl}$ (Fig. 5a). The difference from the ratios of $\mathrm{HCl}(g)$ to $\mathrm{Cl}(p)$ in February and March is likely due to the higher temperature in March (Figs. 3 and 5a). In contrast, the diurnal variations of $\mathrm{HCl}$ and particulate $\mathrm{Cl}$ showed the opposite trend at daytime from 08:00 to 17:00 (Fig. 5b). The mole ratios of $\mathrm{HCl}(g)$ to $\mathrm{Cl}(p)$ ranged from $<0.1$ at nighttime and early morning to $>0.3$ in the afternoon (Fig. 5b). The enhancement of $\mathrm{HCl}(g) / \mathrm{Cl}(p)$ during the noontime is due to the large increase of gaseous $\mathrm{HCl}$. It also suggests that the higher temperature and stronger photochemical reactions during the daytime would strongly influence $\mathrm{HCl}$ release from particulate chloride in Beijing, which will be further discussed in the following sections. During the period between the late afternoon and midnight, the increase of $\mathrm{Cl}(p)$ and $\mathrm{HCl}(g)$ could be explained by the higher nighttime emissions of residential combustion such as wood and coal burning in Beijing (Hu et al., 2017; Sun et al., 2016), and the high abundance of gaseous $\mathrm{HNO}_{3}$ is attributed to efficient nocturnal $\mathrm{N}_{2} \mathrm{O}_{5}$ chemistry (Tham et al., 2018).

These observations showed that there is an abundance of gaseous $\mathrm{HCl}$ and $\mathrm{HBr}$ in the polluted urban environment. To our best of knowledge, this is the first concurrent observation of gaseous $\mathrm{HCl}$ and $\mathrm{HBr}$ in a polluted inland urban atmosphere. Although it is well known that the $\mathrm{HCl}$ is abundant in the polluted coastal and inland regions, previous studies show that the typical $\mathrm{HCl}$ mixing ratios over the continental urban areas are less than 1 ppb (Crisp et al., 2014; Faxon and Allen, 2013; Le Breton et al., 2018; McNamara et al., 2020), which are similar to our observations at Beijing. In contrast, the presence of gaseous $\mathrm{HBr}$ in the urban regions is unknown prior to our observation. The significant concentration of $\mathrm{HBr}$ in the urban atmosphere of Beijing is even comparable to the simulated concentrations in the marine environment, where concentration up to $2 \mathrm{ppt}$ was reported (Fernandez et al., 2014). These elevated $\mathrm{HCl}$ and $\mathrm{HBr}$ in urban Beijing may point to the existence of $\mathrm{Cl}$ and $\mathrm{Br}$ sources in this region.

\subsection{Source identification}

The natural sources of atmospheric $\mathrm{Cl}$ and $\mathrm{Br}$ include sea salt spray, wildfires and volcano emissions, while the anthropogenic emissions include coal combustion and traffic emissions, as well as other industries such as pesticides, battery industry and waste incineration (Simpson et al., 2015). Compared with the sources of particulate $\mathrm{Cl}$ and $\mathrm{Br}$ that are widely studied and identified in previous literature, the origins of gaseous $\mathrm{HCl}$ and $\mathrm{HBr}$ are much less studied, due to 

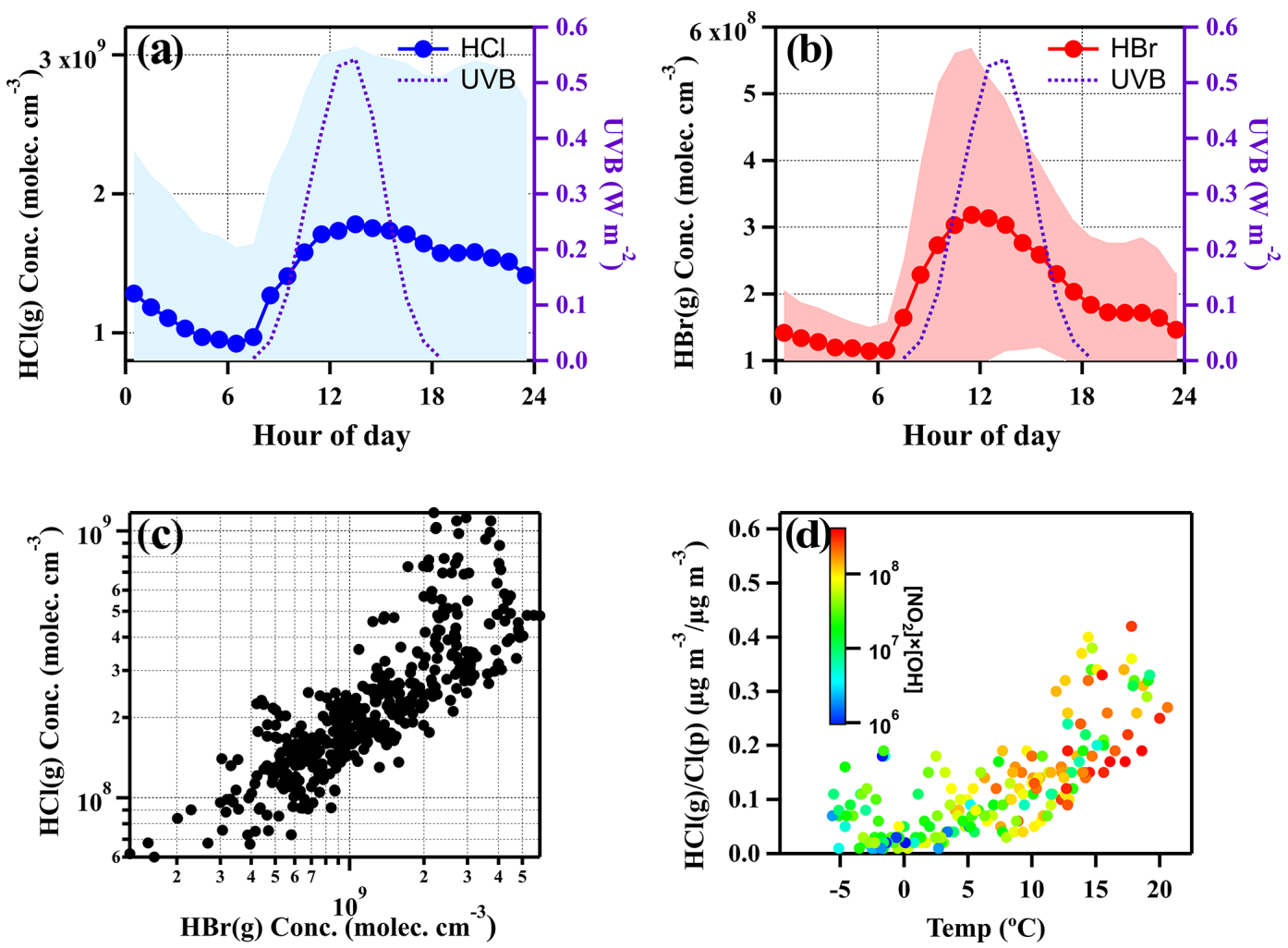

Figure 4. Diurnal variations of UVB intensities, $\mathrm{HCl}$ and $\mathrm{HBr}$ concentrations (averaged values \pm one standard deviation) (a, b) and the correlation between $\mathrm{HCl}$ and $\mathrm{HBr}(\mathbf{c})$. Temperature dependence of gas-particle partitioning ratios of mass concentration of chloride, colorcoded by $\left[\mathrm{NO}_{2}\right] \times[\mathrm{OH}]$, which indicates the abundance of $\mathrm{HNO}_{3}$ in the daytime (d). In panel (c) and (d), the data points are hourly averaged ones during daytime (08:00-17:00). All snowy and rainy days during the sampling period were excluded.
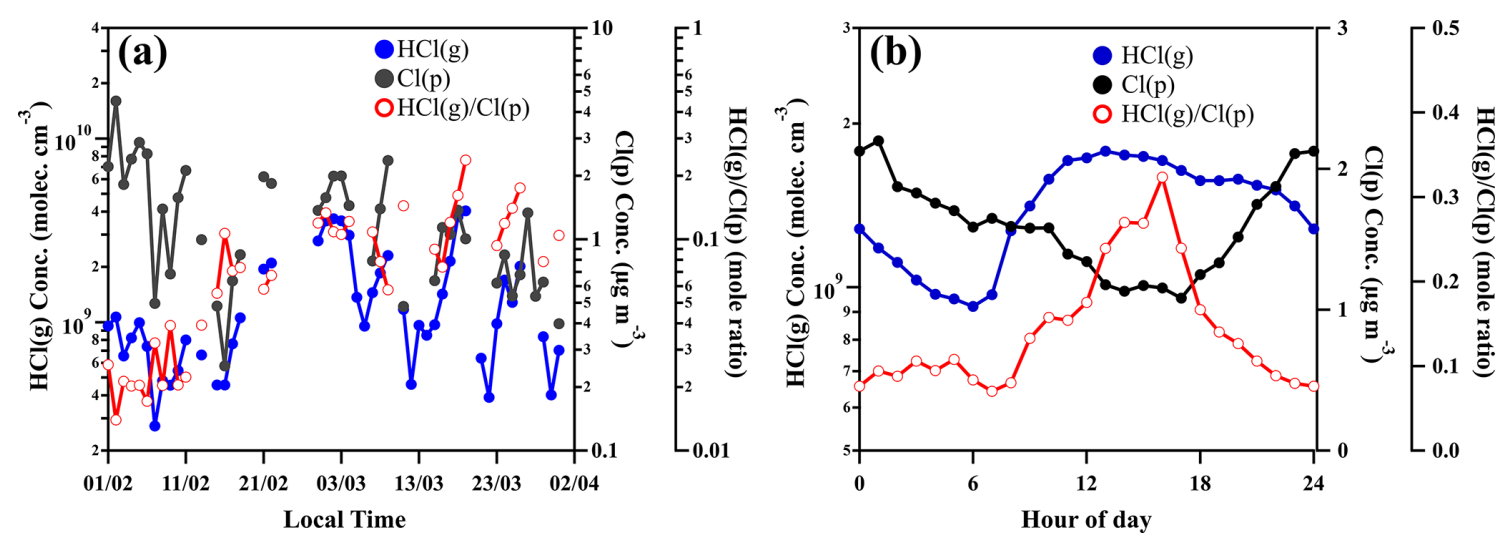

Figure 5. Time variation of daily averaged concentration of particulate chloride $(\mathrm{Cl}(p))$ measured by $\mathrm{ACSM}$, gaseous $\mathrm{HCl}(\mathrm{HCl}(g))$ measured by CI-APi-LTOF and mole ratios of $\mathrm{HCl}(g) / \mathrm{Cl}(p)$ (a) and diurnal variation of $\mathrm{HCl}(g), \mathrm{Cl}(p)$ and mole ratios of $\mathrm{HCl}(g) / \mathrm{Cl}(p)(\mathbf{b})$.

their much shorter lifetime in the troposphere (Simpson et al., 2015).

According to air mass analysis ( $24 \mathrm{~h}$ back-trajectory) for $\mathrm{HCl}$ and $\mathrm{HBr}$ during February and March (Fig. 6a and b), the potential source regions of the selected periods with highlevel concentrations of $\mathrm{HCl}$ (above $75 \%$ percentile) were located in the south of the North China Plain, such as the south of Hebei province, where heavy residential coal, biomass burning and industry emissions occurred (Fu et al., 2018). These figures further suggest that the high concentrations of $\mathrm{HCl}$ seemed not to be strongly affected by marine regions during our sampling period. Instead, the good correlation $(r=0.67)$ between hourly particulate $\mathrm{Cl}$ and $\mathrm{BC}$ together with the similar trend between particulate $\mathrm{Cl}$ and 
$\mathrm{HCl}$ suggested that $\mathrm{HCl}$ is likely to have the same original sources with particulate $\mathrm{Cl}$ and black carbon $(\mathrm{BC})$ in $\mathrm{PM}_{2.5}$ rather than marine sources (Figs. 5a and S10a). Hydrocyanic acid $(\mathrm{HCN})$ and isocyanic acid (HCNO) were typically regarded as tracers for burning emissions, especially in the biomass burning process (Vigouroux et al., 2012; Adachi et al., 2019; Leslie et al., 2019; Wren et al., 2018; Priestley et al., 2018). Although a recent study showed that HCNO came from both primary emissions and secondary formation in the scale of the North China Plain (NCP) during the daytime (Wang et al., 2020), the high correlations between HCN and HCNO (daytime, 08:00-17:00, $r=0.94$ and nighttime, 18:00-07:00, $r=0.96$ ) indicated that in urban Beijing, HCN and $\mathrm{HCNO}$ are mainly from primary emission (Fig. 7c and d) and can be regarded as the tracers of combustion emissions. Thus, high correlations of measured gaseous $\mathrm{HCl}$ with $\mathrm{HCN}(r=0.83)$ and $\mathrm{HCNO}(r=0.90)$ further suggested that the $\mathrm{HCl}$ during our sampling period was more likely coming from combustion origins rather than marine sources in urban Beijing (Fig. 7a and b). Since gaseous $\mathrm{HCl}$ could be affected by both emissions and gas-particle partitioning (shown in Fig. 4d), we compared the daily concentrations of gaseous $\mathrm{HCl}$ and particulate $\mathrm{Cl}$ to minimize the influence of temperature and partitioning. The daily averaged $\mathrm{HCl}$ concentration had a high correlation with daily averaged particulate $\mathrm{Cl}(r=0.84$ and 0.70 for winter and early spring periods, respectively) and $\mathrm{BC}$ concentration $(r=0.82)$, which is consistent with previous studies that particulate $\mathrm{Cl}$, coal combustion organic aerosol (CCOA) and BC were highly correlated and likely to be from the same source in winter and early spring in Beijing (Hu et al., 2017, 2016).

Similar to $\mathrm{HCl}$, the potential source regions for high $\mathrm{Br}$ concentrations were also located in the inland, demonstrating marine sources might not be the dominant source for gaseous $\mathrm{HBr}$ in winter of Beijing (Fig. 6b). The ratio of particulate $\mathrm{Br} / \mathrm{Na}$ from previous literature in Beijing was 0.04 (He et al., 2001), which was much higher than the ratios from seawater (0.018) and crustal dust (0.0006 to 0.0008) but much closer to the ratios of biomass burning aerosols (0.01 to 0.06 ) (Sander et al., 2003). As discussed before, the good correlation ( $r=0.70$ ) between gaseous $\mathrm{HCl}$ and $\mathrm{HBr}$ also implied their similar origins. In our study, moderate correlation coefficients were also observed between gaseous $\mathrm{HBr}$ and combustion tracers such as $\mathrm{HCN}$, HCNO (0.63 and 0.62, respectively) and daily BC ( $r=0.60$ ) (Figs. 7a, b and S10b). Multiple gaseous organic and inorganic $\mathrm{Br}$ compounds such as $\mathrm{CH}_{3} \mathrm{Br}, \mathrm{Br}_{2}, \mathrm{BrNO}_{2}, \mathrm{BrCl}, \mathrm{CH}_{3} \mathrm{Br}$ and $\mathrm{CH}_{2} \mathrm{Br}_{2}$ were also observed in different combustion processes such as biomass burning, coal combustions and waste incineration in previous studies, further supporting the possibilities of combustion origins of the gaseous $\mathrm{HBr}$ in this study (Lee et al., 2018; Keene et al., 1999; Manö and Andreae, 1994). A recent airborne observation conducted in the United States found that high levels of reactive inorganic $\mathrm{Br}$ species in the plume from a coal power plant, likely due to the application of calcium bromide as additives in coal fuel (Lee et al., 2018). Taking these observations together, in urban Beijing, the measured $\mathrm{HBr}$ was more likely coming from combustion sources such as biomass burning and coal combustion in the south of Beijing rather than marine sources. It is also interesting to note that in a previous marine study conducted in Oahu, Hawaii, gaseous $\mathrm{Br}$ was found to be 4 to 10 times higher than particulate $\mathrm{Br}$ (Moyers and Duce, 1972). On the other hand, from a previous observation conducted in urban Beijing, high levels of both gaseous $\left(7 \mathrm{ng} \mathrm{m}^{-3}\right)$ and particulate (in total suspended particles (TSP), $18 \mathrm{ng} \mathrm{m}^{-3}$ ) bromine were measured by an offline sampling-organic solvent extraction and instrumental neutron activation analysis (INAA) method (Tian et al., 2005). Considering the high concentration and reactivity of $\mathrm{Br}$, gaseous $\mathrm{Br}$ from anthropogenic sources may play a more critical role in the urban atmosphere.

\subsection{Halogen-atom production}

To investigate the potential atmospheric implications of $\mathrm{HCl}$ and $\mathrm{HBr}$ on atmospheric oxidation capacity, we calculated the production rate of atomic $\mathrm{Cl}\left(P_{\mathrm{Cl}} \bullet\right)$ and $\mathrm{Br}\left(P_{\mathrm{Br} \bullet}\right)$ via the reactions of $\mathrm{HCl}$ and $\mathrm{HBr}$ with $\mathrm{OH}$ radicals. Figure 8 shows the time series of $P_{\mathrm{Cl}}$. and $P_{\mathrm{Br}}$. and the estimated diel concentration of $\mathrm{OH}$ calculated from the photolysis rate $\left(J_{\mathrm{O} 1 \mathrm{D}}\right)$ (Sect. $\mathrm{S} 8$ ). Note that the estimated peak concentrations of $\mathrm{OH}$ radicals varied between $\sim 3 \times 10^{5}$ and $\sim 4 \times 10^{6}$ molecules $\mathrm{cm}^{-3}$ during noontime. The reaction of $\mathrm{HCl}$ with $\mathrm{OH}$ radicals led to a mean $\mathrm{Cl}$ atom production rate of $3 \times 10^{3}$ molecules $\mathrm{cm}^{-3} \mathrm{~s}^{-1}$ during daytime from 08:00 to $17: 00$ (Fig. 8c). These rates fall within the range of $\mathrm{Cl}$ atom production rates $\left(\sim 10^{3}\right.$ to $10^{6}$ molecules $\left.\mathrm{cm}^{-3} \mathrm{~s}^{-1}\right)$ reported in polluted environments (Crisp et al., 2014; Hoffmann et al., 2018; McNamara et al., 2020). The reaction of $\mathrm{HBr}$ with $\mathrm{OH}$ is estimated to produce a daytime mean of $8 \times 10^{3}$ molecules $\mathrm{cm}^{-3} \mathrm{~s}^{-1}$ of the $\mathrm{Br}$ atom (Fig. $8 \mathrm{c}$ ). This result shows that in addition to the $\mathrm{Cl}$ atom, the $\mathrm{Br}$ atom could also be present in urban Beijing and may be as important as the $\mathrm{Cl}$ atom in terms of reaction with $\mathrm{OH}$, since the $P_{\mathrm{Br}}$ is about 2-3 times faster than the $P_{\mathrm{Cl}}$. (Fig. 8c). The average $\mathrm{HCl}$ and $\mathrm{HBr}$ concentrations were observed to be higher during the polluted days (daily mean $\mathrm{PM}_{2.5} \geq$ $75 \mu \mathrm{g} \mathrm{m}^{-3}$ ), about 2-3 times higher than the clean days (daily mean $\mathrm{PM}_{2.5}<75 \mu \mathrm{g} \mathrm{m}^{-3}$ ), as shown in Fig. 8b. Consequently, the radical production rate also showed a difference between clean and polluted days (Fig. 8d). The mean diurnal pattern shows that the values of $P_{\mathrm{Cl}}$ (up to $8 \times 10^{3}$ molecules $\mathrm{cm}^{-3} \mathrm{~s}^{-1}$ ) and $P_{\mathrm{Br}}$ (up to $2 \times 10^{4}$ molecules $\mathrm{cm}^{-3} \mathrm{~s}^{-1}$ ) on polluted days were both higher than those on clean days by up to 2 times (Fig. 8d). This hints that the roles of $\mathrm{HCl}$ and $\mathrm{HBr}$ may be more significant in polluted environments. Recent studies in several polluted sites of China suggested that the photolysis of $\mathrm{ClNO}_{2}$ and $\mathrm{Cl}_{2}$ is the dominant daytime $\mathrm{Cl}$ atom source, leading to a $\mathrm{Cl}$ atom production rate of up to $8 \times 10^{6}$ molecules $\mathrm{cm}^{-3} \mathrm{~s}^{-1}$ (Tham 
Feb. to Mar. 2019 HCl

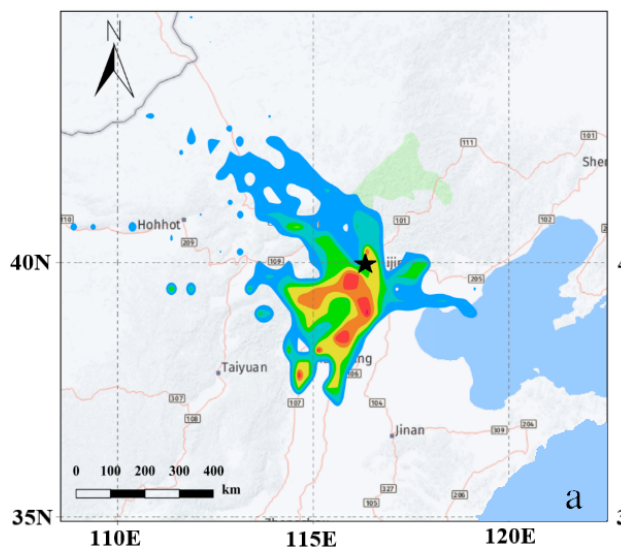

Feb. to Mar. $2019 \mathrm{HBr}$

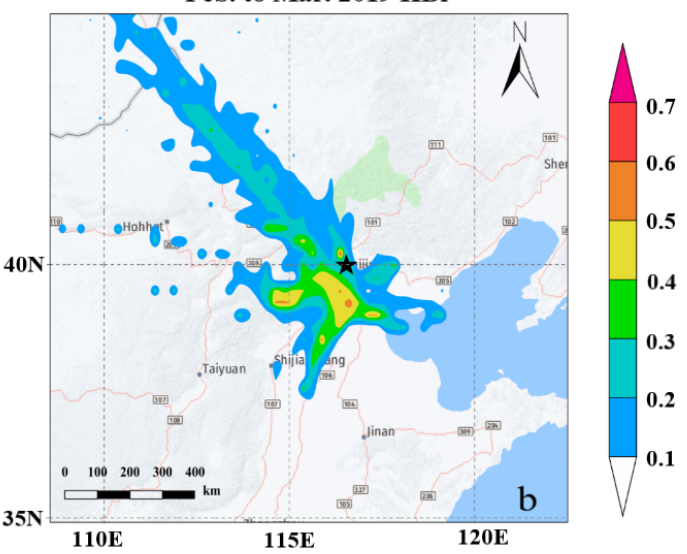

Figure 6. The results of PSCF analysis for $\mathrm{HCl}$ (a) and $\mathrm{HBr}$ (b). Darker colors indicate greater potential source distribution. The terrain base map was made from (C) Yahoo Maps. Black stars mark the location of the sampling site.
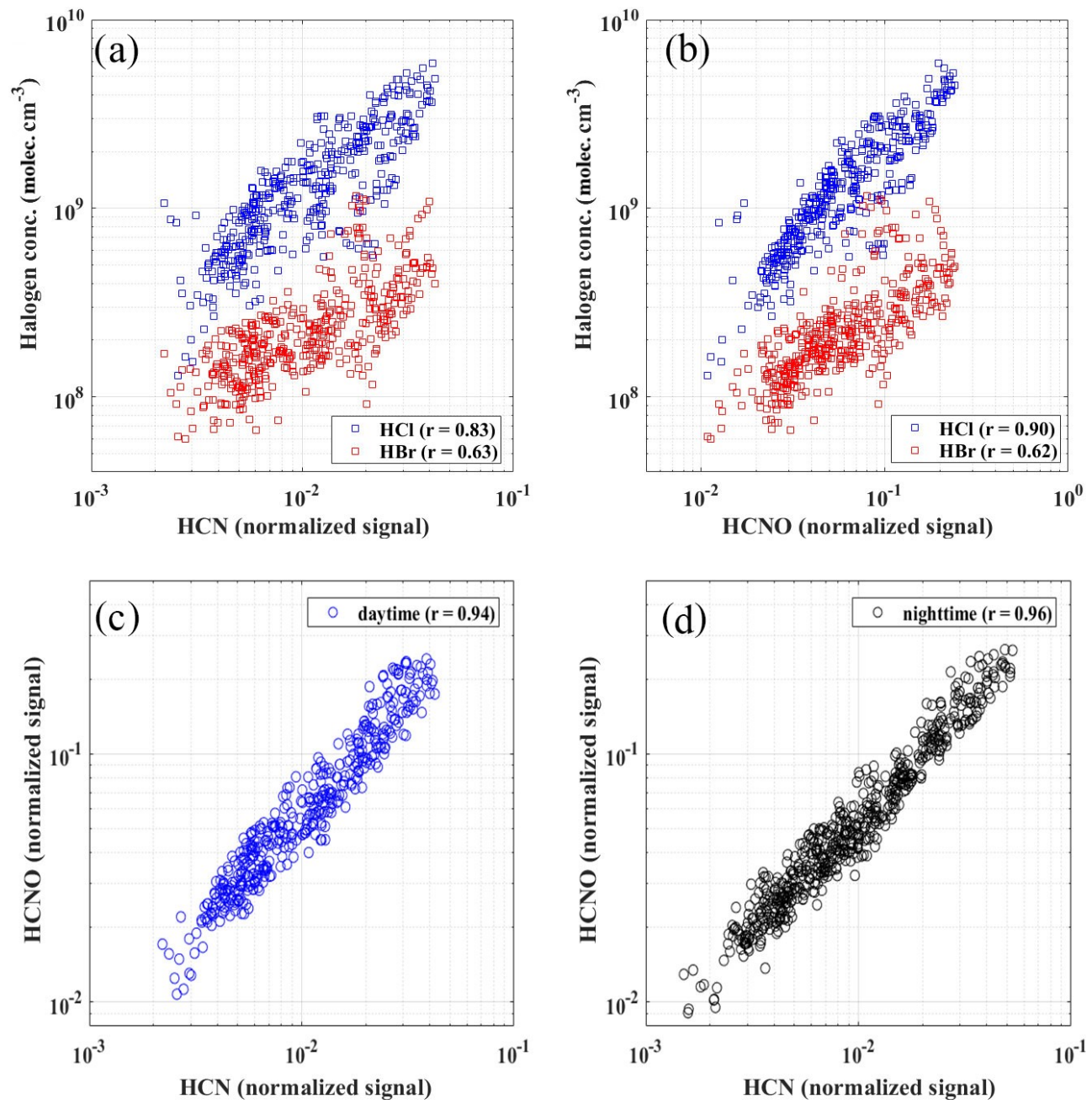

Figure 7. The relationship of $\mathrm{HCl}$ and $\mathrm{HBr}$ concentrations with $\mathrm{HCN}$ and $\mathrm{HCNO}$ during the daytime (08:00-17:00) (a, b) and the correlations between HCN and HCNO during both daytime (08:00-17:00) (c) and nighttime (18:00-07:00 the next day) (d). 

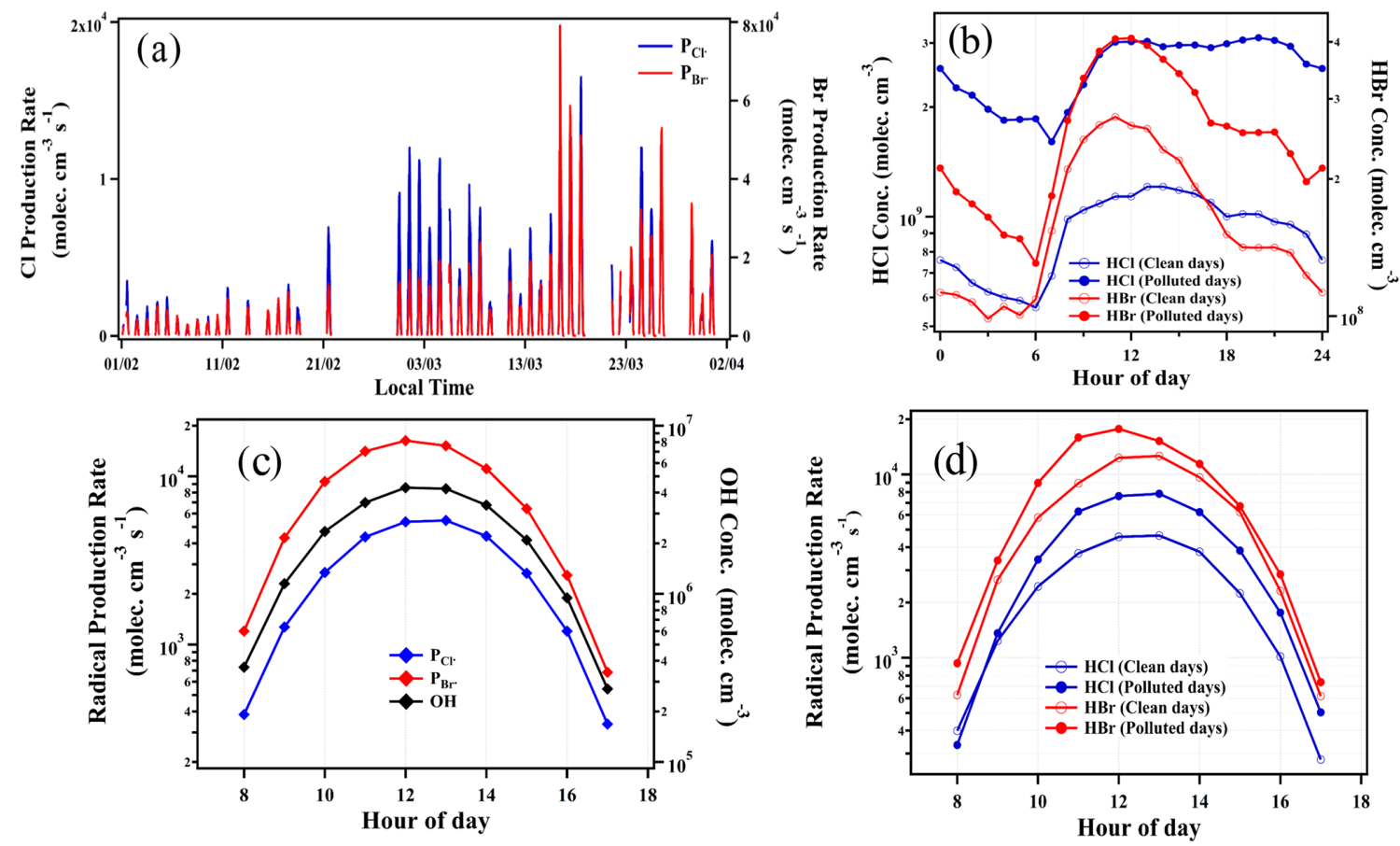

Figure 8. Time series of calculated production rates of $\mathrm{Cl}$ and $\mathrm{Br}$ radicals during the observation period (a); diurnal variations of $\mathrm{HCl}$ and $\mathrm{HBr}$ concentrations on clean and polluted days (b); diurnal variations of production rates of $\mathrm{Cl}$ and $\mathrm{Br}$ radicals from 08:00 to 17:00, together with calculated $\mathrm{OH}$ radical concentrations (c); and production rates of $\mathrm{Cl}$ and $\mathrm{Br}$ radicals on clean and polluted days (d). The clean and polluted days were classified as daily $\mathrm{PM}_{2.5}<75 \mu \mathrm{g} \mathrm{m}{ }^{-3}$ and $\mathrm{PM}_{2.5} \geq 75 \mu \mathrm{g} \mathrm{m}^{-3}$, respectively. The data points are hourly average intervals and measured during observation periods from 1 February to 31 March 2019.

et al., 2016; Liu et al., 2017; Xia et al., 2020), while our observation of the $\mathrm{Cl}$ atom production rate from $\mathrm{HCl}+\mathrm{OH}$ could reach up to $2 \times 10^{4}$ molecules $\mathrm{cm}^{-3} \mathrm{~s}^{-1}$ in the daytime. Despite the lower production rate, the reaction of $\mathrm{HCl}$ with $\mathrm{OH}$ may also act as an important recycling process of the $\mathrm{Cl}$ atom, which ultimately enhanced the atmospheric oxidation capacity (Riedel et al., 2012). Analogous to chlorine chemistry, the reaction of $\mathrm{HBr}$ with $\mathrm{OH}$ could be a significant source of the $\mathrm{Br}$ atom in the daytime, although rapid photolysis of $\mathrm{Br}_{2}$ and $\mathrm{BrNO}_{2}$ is believed to be the major $\mathrm{Br}$ atom source in a polluted urban environment as ubiquitous bromine species (e.g., $\mathrm{Br}_{2}, \mathrm{BrCl}$ and $\mathrm{BrNO}_{2}$ ) have been previously observed in residential coal burning and coal-fired power plant plumes (Lee et al., 2018; Peng et al., 2020).

\section{Conclusions}

In conclusion, we present the first concurrent measurement of both gaseous $\mathrm{HCl}$ and $\mathrm{HBr}$ in urban Beijing, a megacity with strong anthropogenic emissions in the North China Plain. Our observation surprisingly shows significant concentrations of $\mathrm{HBr}$ in urban Beijing, together with the elevated levels of $\mathrm{HCl}$, throughout the winter and spring during our sampling period. Gaseous $\mathrm{HCl}$ and $\mathrm{HBr}$ are most likely originated from anthropogenic emissions such as burning ac- tivities (e.g., biomass burning and fossil fuel combustion) in the inland region rather than marine sources. In addition, the gas-particle partitioning may play a crucial role in contributing to elevated levels of $\mathrm{HCl}$ and $\mathrm{HBr}$ in urban Beijing. On polluted days, the concentrations of $\mathrm{HCl}$ and $\mathrm{HBr}$ are higher than those on clean days. The abundance of $\mathrm{HCl}$ and $\mathrm{HBr}$ in the polluted urban troposphere may further influence the photochemistry of the atmosphere through the following two aspects: (1) direct contributions to the production of highly reactive halogen atom (e.g., $\mathrm{Cl} \cdot$ and $\mathrm{Br} \cdot$ ), which can rapidly oxidize VOCs (Reaction R5); and (2) replenishment of the halide ion $\left(\mathrm{Cl}^{-}\right.$and $\left.\mathrm{Br}^{-}\right)$in the aerosols, supporting the nocturnal heterogeneous production of $\mathrm{ClNO}_{2}$ and $\mathrm{BrNO}_{2}$, which are major sources of highly reactive halogen atom at sunrise (Reactions R3 and R4). Our observation of elevated $\mathrm{HCl}$ and $\mathrm{HBr}$ may indicate an important recycling pathway of $\mathrm{Cl}$ and $\mathrm{Br}$ species and may provide a plausible explanation for the recent observations of widespread halogen activation in polluted areas of China (e.g., Tham et al., 2016; Zhou et al., 2018; Xia et al., 2020; Peng et al., 2020), which could have a significant influence on the atmospheric oxidation capacity and secondary aerosol formation. The atomic $\mathrm{Cl}$ and $\mathrm{Br}$ on polluted days might contribute to oxidation capacity to a greater extent than on clean days. Furthermore, additional insight into the $\mathrm{HBr}$ levels in Beijing shows that bromine chemistry, a previously neglected chemistry, may be 
important in inland megacities of China. Our results also suggest that understanding of gaseous $\mathrm{HCl}$ and $\mathrm{HBr}$ would be of much importance to photochemistry studies, as well as air quality improvement in urban areas of China.

Code and data availability. All data related to this study can be obtained from the corresponding authors (Lei Yao and Yee Jun Tham) via email.

Supplement. The supplement related to this article is available online at: https://doi.org/10.5194/acp-21-11437-2021-supplement.

Author contributions. LY and YJT designed the research. XF, LY, YJT, JC, CY, YG, CL, KRD, FZ, ZL, BC, YW, LD, WD, JK, JTK, JZ, QZ, TK, SI, TP, DRW, VMK, YL, FB and MK carried out the observation, analyzed the data and interpreted the results. SI and TK provided quantum calculation results. XF, LY, YJT and JC prepared the manuscript with contributions from all co-authors.

Competing interests. The authors declare that they have no conflict of interest.

Disclaimer. Publisher's note: Copernicus Publications remains neutral with regard to jurisdictional claims in published maps and institutional affiliations.

Special issue statement. This article is part of the special issue "Pan-Eurasian Experiment (PEEX) - Part II". It is not associated with a conference.

Acknowledgements. The work is supported by the Academy of Finland (ACCC Flagship, grant no. 337549, Center of Excellence in Atmospheric Sciences, project no. 307331, and PROFI3 funding, 311932), the European Research Council via ATM-GTP (grant no. 742206), CHAPAs (grant no. 850614) and the EMME-CARE project, which has received funding from the European Union's Horizon 2020 Research and Innovation.

Financial support. This research has been supported by the Academy of Finland (ACCC Flagship, grant no. 337549, Center of Excellence in Atmospheric Sciences, project no. 307331, and PROFI3 funding, 311932) and the European Research Council via ATM-GTP (grant no. 742206) and CHAPAs (grant no. 850614).

Open-access funding was provided by the Helsinki University Library.

Review statement. This paper was edited by Thorsten BartelsRausch and reviewed by three anonymous referees.

\section{References}

Adachi, K., Sedlacek, A. J., Kleinman, L., Springston, S. R., and Buseck, P. R.: Spherical tarball particles form through rapid chemical and physical changes of organic matter in biomassburning smoke, P. Natl. Acad. Sci. USA, 116, 201900129, https://doi.org/10.1073/pnas.1900129116, 2019.

Arnold, S., Morris, R., Viggiano, A., and Jayne, J.: Ion chemistry relevant for chemical ionization detection of $\mathrm{SO}_{3}$, J. Geophys. Res-Atmos., 100, 14141-14146, https://doi.org/10.1029/95JD01004, 1995.

Artiglia, L., Edebeli, J., Orlando, F., Chen, S., Lee, M.-T., Corral Arroyo, P., Gilgen, A., Bartels-Rausch, T., Kleibert, A., Vazdar, M., Carignano, M. A., Francisco, J. S., Shepson, P. B., Gladich, I., and Ammann, M.: A surface-stabilized ozonide triggers bromide oxidation at the aqueous solution-vapour interface, Nat. Commun., 8, 700, https://doi.org/10.1038/s41467-017-00823-x, 2017.

Atkinson, R., Baulch, D. L., Cox, R. A., Crowley, J. N., Hampson, R. F., Hynes, R. G., Jenkin, M. E., Rossi, M. J., and Troe, J.: Evaluated kinetic and photochemical data for atmospheric chemistry: Volume III - gas phase reactions of inorganic halogens, Atmos. Chem. Phys., 7, 981-1191, https://doi.org/10.5194/acp7-981-2007, 2007.

Bannan, T. J., Khan, M. A. H., Le Breton, M., Priestley, M., Worrall, S. D., Bacak, A., Marsden, N. A., Lowe, D., Pitt, J., Allen, G., Topping, D., Coe, H., McFiggans, G., Shallcross, D. E., and Percival, C. J.: A Large Source of Atomic Chlorine From $\mathrm{ClNO}_{2}$ Photolysis at a U.K. Landfill Site, Geophys. Res. Lett., 46, 85088516, https://doi.org/10.1029/2019GL083764, 2019.

Bedjanian, Y. and Poulet, G.: Kinetics of halogen oxide radicals in the stratosphere, Chem. Rev., 103, 4639, https://doi.org/10.1021/cr0205210, 2003.

Brown, S. S. and Stutz, J.: Nighttime radical observations and chemistry, Chem. Soc. Rev., 41, 6405-6447, https://doi.org/10.1039/C2CS35181A, 2012.

Cai, J., Wang, J., Zhang, Y., Tian, H., Zhu, C., Gross, D. S., Hu, M., Hao, J., He, K., and Wang, S.: Source apportionment of $\mathrm{Pb}$-containing particles in Beijing during January 2013, Environ. Pollut., 226, 30-40, https://doi.org/10.1016/j.envpol.2017.04.004, 2017.

Cai, J., Chu, B., Yao, L., Yan, C., Heikkinen, L. M., Zheng, F., Li, C., Fan, X., Zhang, S., Yang, D., Wang, Y., Kokkonen, T. V., Chan, T., Zhou, Y., Dada, L., Liu, Y., He, H., Paasonen, P., Kujansuu, J. T., Petäjä, T., Mohr, C., Kangasluoma, J., Bianchi, F., Sun, Y., Croteau, P. L., Worsnop, D. R., Kerminen, V.-M., Du, W., Kulmala, M., and Daellenbach, K. R.: Size-segregated particle number and mass concentrations from different emission sources in urban Beijing, Atmos. Chem. Phys., 20, 1272112740, https://doi.org/10.5194/acp-20-12721-2020, 2020.

Calvert, J. and Lindberg, S.: The potential influence of iodinecontaining compounds on the chemistry of the troposphere in the polar spring. II. Mercury depletion, Atmos. Environ., 38, 51055116, 2004.

Chen, D., Huey, L. G., Tanner, D. J., Salawitch, R. J., Anderson, D. C., Wales, P. A., Pan, L. L., Atlas, E. L., Hornbrook, R. S., Apel, E. C., Blake, N. J., Campos, T. L., Donets, V., Flocke, F. M., Hall, S. R., Hanisco, T. F., Hills, A. J., Honomichl, S. B., Jensen, J. B., Kaser, L., Montzka, D. D., Nicely, J. M., Reeves, J. M., Riemer, D. D., Schauffler, S. M., Ullmann, K., Weinheimer, A. J., and 
Wolfe, G. M.: Airborne measurements of $\mathrm{BrO}$ and the sum of $\mathrm{HOBr}$ and $\mathrm{Br}_{2}$ over the Tropical West Pacific from 1 to $15 \mathrm{~km}$ during the CONvective TRansport of Active Species in the Tropics (CONTRAST) experiment, J. Geophys. Res-Atmos., 121, 12560-12578, https://doi.org/10.1002/2016JD025561, 2016.

Chu, B. W., Dada, L., Liu, Y. C., Yao, L., Wang, Y. H., Du, W., Cai, J., Dallenbach, K. R., Chen, X. M., Simonen, P., Zhou, Y., Deng, C. J., Fu, Y. Y., Yin, R. J., Li, H. Y., He, X. C., Feng, Z. M., Yan, C., Kangasluoma, J., Bianchi, F., Jiang, J. K., Kujansuu, J., Kerminen, V. M., Petaja, T., He, H., and Kulmala, M.: Particle growth with photochemical age from new particle formation to haze in the winter of Beijing, China, Sci. Total Environ., 753, 142207, https://doi.org/10.1016/j.scitotenv.2020.142207, 2021.

Crisp, T., Lerner, B., Williams, E., Quinn, P., Bates, T., and Bertram, T.: Observations of gas-phase hydrochloric acid in the polluted marine boundary layer, J. Geophys. Res.-Atmos., 119, 68976915, https://doi.org/10.1002/2013JD020992, 2014.

Eisele, F. L. and Tanner, D. J.: Measurement of the Gas-Phase Concentration of $\mathrm{H}_{2} \mathrm{SO}_{4}$ and Methane Sulfonic-Acid and Estimates of $\mathrm{H}_{2} \mathrm{SO}_{4}$ Production and Loss in the Atmosphere, J. Geophys. Res.-Atmos., 98, 9001-9010, 1993.

Faxon, C. B. and Allen, D. T.: Chlorine chemistry in urban atmospheres: a review, Environ. Chem., 10, 221-233, https://doi.org/10.1071/EN13026, 2013.

Ferguson, E. E., Dunkin, D. B., and Fehsenfeld, F. C.: Reactions of $\mathrm{NO}_{2}^{-}$and $\mathrm{NO}_{3}^{-}$with $\mathrm{HCl}$ and $\mathrm{HBr}$, J. Chem. Phys., 57, 1459$1463,1972$.

Fernandez, R. P., Salawitch, R. J., Kinnison, D. E., Lamarque, J.-F., and Saiz-Lopez, A.: Bromine partitioning in the tropical tropopause layer: implications for stratospheric injection, Atmos. Chem. Phys., 14, 13391-13410, https://doi.org/10.5194/acp-1413391-2014, 2014.

Finlayson-Pitts, B. J., Ezell, M. J., and Pitts, J. N.: Formation of chemically active chlorine compounds by reactions of atmospheric $\mathrm{NaCl}$ particles with gaseous $\mathrm{N}_{2} \mathrm{O}_{5}$ and $\mathrm{ClONO}_{2}$, Nature, 337, 241-244, https://doi.org/10.1038/337241a0, 1989.

Fu, X., Wang, T., Wang, S., Zhang, L., Cai, S., Xing, J., and Hao, J.: Anthropogenic Emissions of Hydrogen Chloride and Fine Particulate Chloride in China, Environ. Sci. Technol., 52, 1644-1654, 2018.

Gard, E. E., Kleeman, M. J., Gross, D. S., Hughes, L. S., Allen, J. O., Morrical, B. D., Fergenson, D. P., Dienes, T., E. Gälli, M., Johnson, R. J., Cass, G. R., and Prather, K. A.: Direct Observation of Heterogeneous Chemistry in the Atmosphere, Science, 279, 1184, https://doi.org/10.1126/science.279.5354.1184, 1998.

Glasow, R. V. and Crutzen, P. J.: Tropospheric Halogen Chemistry, Treatise on Geochemistry, 5, 19-69, 2014.

Graedel, T. E. and Keene, W. C.: Tropospheric budget of reactive chlorine, Global Biogeochem. Cy., 9, 47-77, 1995.

Hara, H., Kato, T., and Matsushita, H.: The Mechanism of Seasonal Variation in the Size Distributions of Atmospheric Chloride and Nitrate Aerosol in Tokyo, B. Chem. Soc. Jpn., 62, 2643-2649, https://doi.org/10.1246/bcsj.62.2643, 1989.

Haskins, J. D., Jaeglé, L., Shah, V., Lee, B. H., Lopez-Hilfiker, F. D., Campuzano-Jost, P., Schroder, J. C., Day, D. A., Guo, H., Sullivan, A. P., Weber, R., Dibb, J., Campos, T., Jimenez, J. L., Brown, S. S., and Thornton, J. A.: Wintertime GasParticle Partitioning and Speciation of Inorganic Chlorine in the Lower Troposphere Over the Northeast United States and
Coastal Ocean, J. Geophys. Res.-Atmos., 123, 12897-12916, https://doi.org/10.1029/2018JD028786, 2018.

He, K. B., Yang, F. M., Ma, Y. L., Zhang, Q., Yao, X. H., Chan, C. K., Cadle, S., Chan, T., and Mulawa, P.: The characteristics of $\mathrm{PM}_{2.5}$ in Beijing, China, Atmos. Environ., 35, 4959-4970, https://doi.org/10.1016/s1352-2310(01)00301-6, 2001.

Hoffmann, E., Tilgner, A., Wolke, R., and Herrmann, H.: Enhanced Chlorine and Bromine Atom Activation by Hydrolysis of Halogen Nitrates from Marine Aerosols at Polluted Coastal Areas, Environ. Sci. Technol., 53, 771-778, https://doi.org/10.1021/acs.est.8b05165, 2018.

Hu, W., Hu, M., Hu, W., Jimenez, J., Yuan, B., Chen, W., Wang, M., Wu, Y., Chen, C., Wang, Z., Peng, J., Zeng, L., and Shao, M.: Chemical composition, sources, and aging process of submicron aerosols in Beijing: Contrast between summer and winter, J. Geophys. Res.-Atmos., 121, 1955-1977, https://doi.org/10.1002/2015JD024020, 2016.

Hu, W., Hu, M., Hu, W.-W., Zheng, J., Chen, C., Wu, Y., and Guo, S.: Seasonal variations in high time-resolved chemical compositions, sources, and evolution of atmospheric submicron aerosols in the megacity Beijing, Atmos. Chem. Phys., 17, 9979-10000, https://doi.org/10.5194/acp-17-9979-2017, 2017.

Junninen, H., Ehn, M., Petäjä, T., Luosujärvi, L., Kotiaho, T., Kostiainen, R., Rohner, U., Gonin, M., Fuhrer, K., Kulmala, M., and Worsnop, D. R.: A high-resolution mass spectrometer to measure atmospheric ion composition, Atmos. Meas. Tech., 3, 10391053, https://doi.org/10.5194/amt-3-1039-2010, 2010.

Keene, W. C., Khalil, M. A. K., Erickson, D. J., McCulloch, A., Graedel, T. E., Lobert, J. M., Aucott, M. L., Gong, S. L., Harper, D. B., Kleiman, G., Midgley, P., Moore, R. M., Seuzaret, C., Sturges, W. T., Benkovitz, C. M., Koropalov, V., Barrie, L. A., and Li, Y. F.: Composite global emissions of reactive chlorine from anthropogenic and natural sources: Reactive Chlorine Emissions Inventory, J. Geophys. Res.-Atmos., 104, 8429-8440, https://doi.org/10.1029/1998jd100084, 1999.

Kontkanen, J., Deng, C., Fu, Y., Dada, L., Zhou, Y., Cai, J., Daellenbach, K. R., Hakala, S., Kokkonen, T. V., Lin, Z., Liu, Y., Wang, Y., Yan, C., Petäjä, T., Jiang, J., Kulmala, M., and Paasonen, P.: Size-resolved particle number emissions in Beijing determined from measured particle size distributions, Atmos. Chem. Phys., 20, 11329-11348, https://doi.org/10.5194/acp-20-113292020, 2020.

Lammel, G., Röhrl, A., and Schreiber, H.: Atmospheric lead and bromine in Germany, Environ. Sci. Pollut. Res., 9, 397, https://doi.org/10.1007/BF02987589, 2002.

Le Breton, M., Hallquist, Å. M., Pathak, R. K., Simpson, D., Wang, Y., Johansson, J., Zheng, J., Yang, Y., Shang, D., Wang, H., Liu, Q., Chan, C., Wang, T., Bannan, T. J., Priestley, M., Percival, C. J., Shallcross, D. E., Lu, K., Guo, S., Hu, M., and Hallquist, M.: Chlorine oxidation of VOCs at a semi-rural site in Beijing: significant chlorine liberation from $\mathrm{ClNO}_{2}$ and subsequent gas- and particle-phase $\mathrm{Cl}-\mathrm{VOC}$ production, Atmos. Chem. Phys., 18, 13013-13030, https://doi.org/10.5194/acp-1813013-2018, 2018.

Lee, B. H., Lopez-Hilfiker, F. D., Schroder, J. C., Campuzano-Jost, P., Jimenez, J. L., McDuffie, E. E., Fibiger, D. L., Veres, P. R., Brown, S. S., Campos, T. L., Weinheimer, A. J., Flocke, F. F., Norris, G., O’Mara, K., Green, J. R., Fiddler, M. N., Bililign, S., Shah, V., Jaegle, L., and Thornton, J. A.: Airborne Observations 
of Reactive Inorganic Chlorine and Bromine Species in the Exhaust of Coal-Fired Power Plants, J. Geophys. Res.-Atmos., 123, 11225-11237, https://doi.org/10.1029/2018JD029284, 2018.

Leslie, M. D., Ridoli, M., Murphy, J. G., and Borduas-Dedekind, N.: Isocyanic acid (HNCO) and its fate in the atmosphere: a review, Environ. Sci.: Processes Impacts, 21, 793-808, https://doi.org/10.1039/C9EM00003H, 2019.

Li, Q., Badia, A., Wang, T., Sarwar, G., Fu, X., Zhang, L., Zhang, Q., Fung, J., Cuevas, C. A., Wang, S., Zhou, B., and SaizLopez, A.: Potential Effect of Halogens on Atmospheric Oxidation and Air Quality in China, J. Geophys. Res.-Atmos., 125, e2019JD032058, https://doi.org/10.1029/2019JD032058, 2020.

Liu, X., Qu, H., Huey, L. G., Wang, Y., Sjostedt, S., Zeng, L., Lu, K., Wu, Y., Hu, M., Shao, M., Zhu, T., and Zhang, Y.: High Levels of Daytime Molecular Chlorine and Nitryl Chloride at a Rural Site on the North China Plain, Environ. Sci. Technol., 51, 9588-9595, https://doi.org/10.1021/acs.est.7b03039, 2017.

Manö, S. and Andreae, M. O.: Emission of Methyl Bromide from Biomass Burning, Science, 263, 1255-1257, 1994.

McNamara, S. M., Kolesar, K. R., Wang, S., Kirpes, R. M., May, N. W., Gunsch, M. J., Cook, R. D., Fuentes, J. D., Hornbrook, R. S., Apel, E. C., China, S., Laskin, A., and Pratt, K. A.: Observation of Road Salt Aerosol Driving Inland Wintertime Atmospheric Chlorine Chemistry, ACS Central Science, 6, 684-694, https://doi.org/10.1021/acscentsci.9b00994, 2020.

Mielke, L. H., Furgeson, A., and Osthoff, H. D.: Observation of $\mathrm{ClNO}_{2}$ in a Mid-Continental Urban Environment, Environ. Sci. Technol., 45, 8889-8896, https://doi.org/10.1021/es201955u, 2011.

Moyers, J. L. and Duce, R. A.: Gaseous and particulate bromine in the marine atmosphere, J. Geophys. Res., 77, 5330-5338, https://doi.org/10.1029/JC077i027p05330, 1972.

Nolt, I. G., Ade, P., Alboni, F., Carli, B., Carlotti, M., Cortesi, U., Epifani, M., Griffin, M. J., Hamilton, P. A., Lee, C., Lepri, G., Mencaraglia, F., Murray, A. G., Park, J. H., Park, K., Raspollini, P., Ridolfi, M., and Vanek, M. D.: Stratospheric $\mathrm{HBr}$ concentration profile obtained from far-infrared emission spectroscopy, Geophys. Res. Lett., 24, 281-284, https://doi.org/10.1029/97GL00034, 1997.

Osthoff, H. D., Roberts, J. M., Ravishankara, A. R., Williams, E. J., Lerner, B. M., Sommariva, R., Bates, T. S., Coffman, D., Quinn, P. K., Dibb, J. E., Stark, H., Burkholder, J. B., Talukdar, R. K., Meagher, J., Fehsenfeld, F. C., and Brown, S. S.: High levels of nitryl chloride in the polluted subtropical marine boundary layer, Nat. Geosci., 1, 324-328, https://doi.org/10.1038/ngeo177, 2008.

Peng, X., Wang, W., Xia, M., Chen, H., Ravishankara, A., Li, Q., Alfonso, S.-L., Liu, P., Zhang, F., Zhang, C., Xue, L., Wang, X., George, C., Wang, J., Mu, Y., Chen, J.-M., and Tao, W.: An unexpected large continental source of reactive bromine and chlorine with significant impact on wintertime air quality, Natl. Sci. Rev., nwaa304, https://doi.org/10.1093/nsr/nwaa304, 2020.

Phillips, G. J., Tang, M. J., Thieser, J., Brickwedde, B., Schuster, G., Bohn, B., Lelieveld, J., and Crowley, J. N.: Significant concentrations of nitryl chloride observed in rural continental Europe associated with the influence of sea salt chloride and anthropogenic emissions, Geophys. Res. Lett., 39, L10811, https://doi.org/10.1029/2012GL051912, 2012.
Priestley, M., Breton, M., Bannan, T., Leather, K., Bacak, A., Reyes Villegas, E., Vocht, F., Shallcross, B., Brazier, T., Khan, A., Allan, J., Shallcross, D., Coe, H., and Percival, C.: Observations of Isocyanate, Amide, Nitrate, and Nitro Compounds From an Anthropogenic Biomass Burning Event Using a ToF-CIMS, J. Geophys. Res.-Atmos., 123, 7687-7704, https://doi.org/10.1002/2017JD027316, 2018.

Riedel, T. P., Bertram, T. H., Crisp, T. A., Williams, E. J., Lerner, B. M., Vlasenko, A., Li, S.-M., Gilman, J., de Gouw, J., Bon, D. M., Wagner, N. L., Brown, S. S., and Thornton, J. A.: Nitryl Chloride and Molecular Chlorine in the Coastal Marine Boundary Layer, Environ. Sci. Technol., 46, 10463-10470, https://doi.org/10.1021/es204632r, 2012.

Riedel, T. P., Wagner, N. L., Dubé, W. P., Middlebrook, A. M., Young, C. J., Öztürk, F., Bahreini, R., VandenBoer, T. C., Wolfe, D. E., Williams, E. J., Roberts, J. M., Brown, S. S., and Thornton, J. A.: Chlorine activation within urban or power plant plumes: Vertically resolved $\mathrm{ClNO}_{2}$ and $\mathrm{Cl}_{2}$ measurements from a tall tower in a polluted continental setting, J. Geophys. Res.-Atmos., 118, 8702-8715, https://doi.org/10.1002/jgrd.50637, 2013.

Roberts, T., Dayma, G., and Oppenheimer, C.: Reaction Rates Control High-Temperature Chemistry of Volcanic Gases in Air, Front. Earth Sci., 7, 154, https://doi.org/10.3389/feart.2019.00154, 2019.

Rotermund, M. K., Bense, V., Chipperfield, M. P., Engel, A., Grooß, J.-U., Hoor, P., Hüneke, T., Keber, T., Kluge, F., Schreiner, B., Schuck, T., Vogel, B., Zahn, A., and Pfeilsticker, K.: Organic and inorganic bromine measurements around the extratropical tropopause and lowermost stratosphere: Insights into the transport pathways and total bromine, Atmos. Chem. Phys. Discuss. [preprint], https://doi.org/10.5194/acp-2021-202, in review, 2021.

Saiz-Lopez, A. and von Glasow, R.: Reactive halogen chemistry in the troposphere, Chem. Soc. Rev., 41, 6448-6472, https://doi.org/10.1039/c2cs35208g, 2012.

Saiz-Lopez, A., Lamarque, J.-F., Kinnison, D. E., Tilmes, S., Ordóñez, C., Orlando, J. J., Conley, A. J., Plane, J. M. C., Mahajan, A. S., Sousa Santos, G., Atlas, E. L., Blake, D. R., Sander, S. P., Schauffler, S., Thompson, A. M., and Brasseur, G.: Estimating the climate significance of halogen-driven ozone loss in the tropical marine troposphere, Atmos. Chem. Phys., 12, 3939-3949, https://doi.org/10.5194/acp-12-3939-2012, 2012.

Sander, R., Keene, W. C., Pszenny, A. A. P., Arimoto, R., Ayers, G. P., Baboukas, E., Cainey, J. M., Crutzen, P. J., Duce, R. A., Hönninger, G., Huebert, B. J., Maenhaut, W., Mihalopoulos, N., Turekian, V. C., and Van Dingenen, R.: Inorganic bromine in the marine boundary layer: a critical review, Atmos. Chem. Phys., 3, 1301-1336, https://doi.org/10.5194/acp-3-1301-2003, 2003.

Sarwar, G., Simon, H., Xing, J., and Mathur, R.: Importance of tropospheric $\mathrm{ClNO}_{2}$ chemistry across the Northern Hemisphere, Geophys. Res. Lett., 41, 4050-4058, https://doi.org/10.1002/2014GL059962, 2014.

Sherwen, T., Evans, M. J., Sommariva, R., Hollis, L. D. J., Ball, S. M., Monks, P. S., Reed, C., Carpenter, L. J., Lee, J. D., Forster, G., Bandy, B., Reeves, C. E., and Bloss, W. J.: Effects of halogens on European air-quality, Faraday Discuss., 200, 75-100, https://doi.org/10.1039/C7FD00026J, 2017.

Simpson, W., Brown, S., Alfonso, S. L., Thornton, J., and Glasow, R.: Tropospheric Halogen Chemistry: Sources, 
Cycling, and Impacts, Chem. Rev., 115, 4035-4062, https://doi.org/10.1021/cr5006638, 2015.

Skalny, J., Mikoviny, T., Matejcik, S., and Mason, N.: An analysis of mass spectrometric study of negative ions extracted from negative corona discharge in air, Int. J. Mass Spectrom., 233, 317324, https://doi.org/10.1016/j.ijms.2004.01.012, 2004.

Stavrakou, T., Müller, J.-F., Boersma, K. F., van der A, R. J., Kurokawa, J., Ohara, T., and Zhang, Q.: Key chemical $\mathrm{NO}_{\mathrm{x}}$ sink uncertainties and how they influence top-down emissions of nitrogen oxides, Atmos. Chem. Phys., 13, 9057-9082, https://doi.org/10.5194/acp-13-9057-2013, 2013.

Sun, Y., Du, W., Fu, P., Wang, Q., Li, J., Ge, X., Zhang, Q., Zhu, C., Ren, L., Xu, W., Zhao, J., Han, T., Worsnop, D. R., and Wang, Z.: Primary and secondary aerosols in Beijing in winter: sources, variations and processes, Atmos. Chem. Phys., 16, 8309-8329, https://doi.org/10.5194/acp-16-8309-2016, 2016.

Tham, Y. J., Yan, C., Xue, L., Zha, Q., Wang, X., and Wang, T.: Presence of high nitryl chloride in Asian coastal environment and its impact on atmospheric photochemistry, Chinese Sci. Bull., 59, 356-359, https://doi.org/10.1007/s11434-013-0063-y, 2014.

Tham, Y. J., Wang, Z., Li, Q., Yun, H., Wang, W., Wang, X., Xue, L., Lu, K., Ma, N., Bohn, B., Li, X., Kecorius, S., Größ, J., Shao, M., Wiedensohler, A., Zhang, Y., and Wang, T.: Significant concentrations of nitryl chloride sustained in the morning: investigations of the causes and impacts on ozone production in a polluted region of northern China, Atmos. Chem. Phys., 16, 14959-14977, https://doi.org/10.5194/acp-16-14959-2016, 2016.

Tham, Y. J., Wang, Z., Li, Q., Wang, W., Wang, X., Lu, K., Ma, N., Yan, C., Kecorius, S., Wiedensohler, A., Zhang, Y., and Wang, T.: Heterogeneous $\mathrm{N}_{2} \mathrm{O}_{5}$ uptake coefficient and production yield of $\mathrm{ClNO}_{2}$ in polluted northern China: roles of aerosol water content and chemical composition, Atmos. Chem. Phys., 18, 1315513171, https://doi.org/10.5194/acp-18-13155-2018, 2018.

Thornton, J. A., Kercher, J. P., Riedel, T. P., Wagner, N. L., Cozic, J., Holloway, J. S., Dubé, W. P., Wolfe, G. M., Quinn, P. K., and Middlebrook, A. M.: A large atomic chlorine source inferred from mid-continental reactive nitrogen chemistry, Nature, 464, 271-274, 2010.

Tian, Q., Xu, D., Chai, Z., Lu, Y., and Xiong, Y.: Analysis on the organic bromine in the atmosphere in Beijing, Journal of Nuclear and Radiochemistry, 27, 236-238, https://doi.org/10.3969/j.issn.0253-9950.2005.04.010, 2005.

Vigouroux, C., Stavrakou, T., Whaley, C., Dils, B., Duflot, V., Hermans, C., Kumps, N., Metzger, J.-M., Scolas, F., Vanhaelewyn, G., Müller, J.-F., Jones, D. B. A., Li, Q., and De Mazière, M.: FTIR time-series of biomass burning products $\left(\mathrm{HCN}, \mathrm{C}_{2} \mathrm{H}_{6}, \mathrm{C}_{2} \mathrm{H}_{2}, \mathrm{CH}_{3} \mathrm{OH}\right.$, and $\left.\mathrm{HCOOH}\right)$ at Reunion Island $\left(21^{\circ} \mathrm{S}, 55^{\circ} \mathrm{E}\right)$ and comparisons with model data, Atmos. Chem. Phys., 12, 10367-10385, https://doi.org/10.5194/acp-12-103672012, 2012.

Wang, D. S. and Ruiz, L. H.: Secondary organic aerosol from chlorine-initiated oxidation of isoprene, Atmos. Chem. Phys., 17, 13491-13508, https://doi.org/10.5194/acp-17-13491-2017, 2017.

Wang, X., Jacob, D. J., Eastham, S. D., Sulprizio, M. P., Zhu, L., Chen, Q., Alexander, B., Sherwen, T., Evans, M. J., Lee, B. H., Haskins, J. D., Lopez-Hilfiker, F. D., Thornton, J. A., Huey, G. L., and Liao, H.: The role of chlorine in global tropospheric chemistry, Atmos. Chem. Phys., 19, 3981-4003, https://doi.org/10.5194/acp-19-3981-2019, 2019.

Wang, Y. Q.: MeteoInfo: GIS software for meteorological data visualization and analysis, Meteorol. Appl., 21, 360-368, https://doi.org/10.1002/met.1345, 2014.

Wang, Y. Q.: An Open Source Software Suite for MultiDimensional Meteorological Data Computation and Visualisation, Journal of Open Research Software, 7, p. 21, https://doi.org/10.5334/jors.267, 2019.

Wang, Z., Wang, W., Tham, Y. J., Li, Q., Wang, H., Wen, L., Wang, $\mathrm{X}$., and Wang, T.: Fast heterogeneous $\mathrm{N}_{2} \mathrm{O}_{5}$ uptake and $\mathrm{ClNO}_{2}$ production in power plant and industrial plumes observed in the nocturnal residual layer over the North China Plain, Atmos. Chem. Phys., 17, 12361-12378, https://doi.org/10.5194/acp-1712361-2017, 2017.

Wang, Z., Yuan, B., Ye, C., Roberts, J., Wisthaler, A., Lin, Y., Li, T., Wu, C., Peng, Y., Wang, C., Wang, S., Yang, S., Wang, B., Qi, J., Wang, C., Song, W., Hu, W., Wang, X., Xu, W., Ma, N., Kuang, Y., Tao, J., Zhang, Z., Su, H., Cheng, Y., Wang, X., and Shao, M.: High Concentrations of Atmospheric Isocyanic Acid (HNCO) Produced from Secondary Sources in China, Environ. Sci. Tech., 54, 11818-11826, https://doi.org/10.1021/acs.est.0c02843, 2020.

Wren, S. N., Liggio, J., Han, Y., Hayden, K., Lu, G., Mihele, C. M., Mittermeier, R. L., Stroud, C., Wentzell, J. J. B., and Brook, J. R.: Elucidating real-world vehicle emission factors from mobile measurements over a large metropolitan region: a focus on isocyanic acid, hydrogen cyanide, and black carbon, Atmos. Chem. Phys., 18, 16979-17001, https://doi.org/10.5194/acp-18-169792018, 2018.

Xia, M., Peng, X., Wang, W., Yu, C., Sun, P., Li, Y., Liu, Y., Xu, Z., Wang, Z., Xu, Z., Nie, W., Ding, A., and Wang, T.: Significant production of $\mathrm{ClNO}_{2}$ and possible source of $\mathrm{Cl}_{2}$ from $\mathrm{N}_{2} \mathrm{O}_{5}$ uptake at a suburban site in eastern China, Atmos. Chem. Phys., 20, 6147-6158, https://doi.org/10.5194/acp-20-6147-2020, 2020.

Yang, X., Cox, R., Warwick, N., Pyle, J., Carver, G., O’Connor, F., and Savage, N.: Tropospheric bromine chemistry and its impacts on ozone: A model study, J. Geophys. Res., 110, D23311, https://doi.org/10.1029/2005JD006244, 2005.

Yang, X., Wang, T., Xia, M., Gao, X., Li, Q., Zhang, N., Gao, Y., Lee, S., Wang, X., Xue, L., Yang, L., and Wang, W.: Abundance and origin of fine particulate chloride in continental China, Sci. Total Environ., 624, 1041-1051, https://doi.org/10.1016/j.scitotenv.2017.12.205, 2018.

Yao, L., Garmash, O., Bianchi, F., Zheng, J., Yan, C., Kontkanen, J., Junninen, H., Mazon, S. B., Ehn, M., Paasonen, P., Sipila, M., Wang, M., Wang, X., Xiao, S., Chen, H., Lu, Y., Zhang, B., Wang, D., Fu, Q., Geng, F., Li, L., Wang, H., Qiao, L., Yang, X., Chen, J., Kerminen, V. M., Petaja, T., Worsnop, D. R., Kulmala, M., and Wang, L.: Atmospheric new particle formation from sulfuric acid and amines in a Chinese megacity, Science, 361, 278281, https://doi.org/10.1126/science.aao4839, 2018.

Yao, L., Fan, X., Yan, C., Kurten, T., Daellenbach, K. R., Li, C., Wang, Y., Guo, Y., Dada, L., Rissanen, M. P., Cai, J., Tham, Y. J., Zha, Q., Zhang, S., Du, W., Yu, M., Zheng, F., Zhou, Y., Kontkanen, J., Chan, T., Shen, J., Kujansuu, J. T., Kangasluoma, J., Jiang, J., Wang, L., Worsnop, D. R., Petaja, T., Kerminen, V. M., Liu, Y., Chu, B., He, H., Kulmala, M., and Bianchi, F.: Unprecedented Ambient Sulfur Tri- 
oxide $\left(\mathrm{SO}_{3}\right)$ Detection: Possible Formation Mechanism and Atmospheric Implications, Environ. Sci. Tech. Let., 7, 809-818, https://doi.org/10.1021/acs.estlett.0c00615, 2020.

Zhou, W., Zhao, J., Ouyang, B., Mehra, A., Xu, W., Wang, Y., Bannan, T. J., Worrall, S. D., Priestley, M., Bacak, A., Chen, Q., Xie, C., Wang, Q., Wang, J., Du, W., Zhang, Y., Ge, X., Ye, P., Lee, J. D., Fu, P., Wang, Z., Worsnop, D., Jones, R., Percival, C. J., Coe, $\mathrm{H}$., and Sun, Y.: Production of $\mathrm{N}_{2} \mathrm{O}_{5}$ and $\mathrm{ClNO}_{2}$ in summer in urban Beijing, China, Atmos. Chem. Phys., 18, 11581-11597, https://doi.org/10.5194/acp-18-11581-2018, 2018.
Zhou, Y., Dada, L., Liu, Y., Fu, Y., Kangasluoma, J., Chan, T., Yan, C., Chu, B., Daellenbach, K. R., Bianchi, F., Kokkonen, T. V., Liu, Y., Kujansuu, J., Kerminen, V.-M., Petäjä, T., Wang, L., Jiang, J., and Kulmala, M.: Variation of size-segregated particle number concentrations in wintertime Beijing, Atmos. Chem. Phys., 20, 1201-1216, https://doi.org/10.5194/acp-201201-2020, 2020. 